\title{
Milli Gelir, Bankacılık Kredi ve Mevduat Hacmi ile Menkul Kıymetler Borsası İşlem Hacmi Etkileşimi
}

DOI: 10.26466/opus.588751

\author{
Mustafa Canbaz* \\ * Dr. Öğr. Üyesi, Afyonkarahisar Sağlık Bilimleri Üni., Sağlık Bilimleri Fak., Sağlık Yönetimi Böl. \\ E-Posta: mcanbaz67@yahoo.com \\ ORCID: $0000-0002-5261-6187$
}

Öz

Gayri safi milli gelir ile finansal göstergeler ülkelerin gelişmişliği hakkında önemli verilerdir. Ülkeler, bu göstergeler esas alınarak sinıflandırılmış olsalar da, temelde diğer sosyal göstergeler de belirleyicidir. Bu çalışma, söz konusu göstergelerden banka mevduat ve krediler ile gayri safi milli gelir ve hisse senetleri piyasasındaki işlem hacmi değiş̧kenleri arasındaki etkileşimi araştırmak amacıyla yapılmıştır. Ek olarak, analiz döneminde yaşanan 2008 krizinin değişkenler üzerinde yapısal kurılma yapıpyapmadığı araştırılmışıır. Çalışma kapsamına bu dört değişkenin 2002 ile 2011 arası dönem verileri alınmıştır. Analizde kullanılan temel yöntem, vektör otoregresif (VAR) modeldir. Elde edilen sonuçlara göre, uzun dönemde banka mevduat hacmi en dişşal, ikinci en az dişsal değişken menkul kıymetler borsası işlem hacmi olmuştur. Buna karşılık, beklendiği gibi, en yüksek dışsallık milli gelirdir. Milli gelir, önemli oranda dış faktörlere bağhldır. Elde edilen bu sonuçlar genel teori ve diğer çalışmalarla benzerdir. Ayrıca değişkenlerin diğer değişkenlere katkısı önemli düzeydedir. Öte yandan, bankalar mevduatı 2004'ün ilk çeyreği ile 2006'nın ilk çeyreğinde 'kırılma' yaşamıştır. Buna karşılık banka kredileri 2008'in üçüncü çeyreğinde 'kırılma' yaşamıştır. Böylece, 2007 sonbaharında başlayan küresel kriz mevduatlara kriz öncesi yansırken, kredilere sonrasında yansımışıtır.

Anahtar Kelimeler: Bankacıllk, mevduat ve kredi hacmi, işlem hacmi, gayrisafi milli gelir, vektör otoregresif (VAR) model Jel Kodu: G24, D53, H81, E44, C58 


\title{
Interaction of National Income, Banking Credit, Deposit Volume and Stock Exchange Transaction Volume
}

\begin{abstract}
Gross national income and financial indicators are important data on the development of countries. Although countries are classified on the basis of these indicators, other social indicators are also determinative. This study was conducted to investigate the interaction between bank deposits and loans and the trading volume variables in the gross national income and equities market. In addition, it was investigated whether the 2008 crisis experienced during the analysis period had structural refraction on the variables. The data for the period between 2002 and 2011 of these four variables were taken into the scope of the study. The basic method used in analysis is the vector autoregressive (VAR) model. According to the results, bank deposit volume in the long term was the most external, and the second least external variable was the stock exchange trading volume. In contrast, as expected, the highest externality is national income. National income depends significantly on external factors. These results are similar to General Theory and other studies. In addition, the contribution of variables to other variables is significant. On the other hand, banks 'deposits experienced' breakdowns ' in the first quarter of 2004 and the first quarter of 2006. In contrast, bank lending experienced a 'break-even' in the third quarter of 2008. Thus, the global crisis that began in the fall of 2007 reflected deposits before the crisis, while loans were reflected after.
\end{abstract}

Keywords Banking, deposit and credit volume, transaction volume, gross national product, vector autoregressive model Jel Kodes: G24, D53, H81, E44, C58 


\section{Giriş}

Günümüz ekonomik şartlarında finansal piyasaların önemi öylesine artmıştır ki bu piyasalardaki gelişmeler reel üretimdeki gelişmelere göre daha yakından izlenir hale gelmiştir. Yanı sıra, gelişmiş birçok ülkenin finansal sektör piyasa değerleri, milli gelirlerinin çok üzerinde seyreder olmuştur. Bu durum, tabiidir ki, bu alandaki yatırımcıların hem niteliksel hem de niceliksel anlamda ilgisini arttırmaktadır. Bu gelişim, sadece bu ülkelerin değil gelişmekte olan ülkelerinde gerek araştırma kaynaklarını, gerekse de düşünsel kaynaklarını finans piyasalarına doğru kaydirmaktadır.

Ülke içi tasarrufun yatırıma ve nihayet gayri safi yurt içi hasılaya etkin biçimde dönüşebilmesi, sermaye piyasalarının sağlıklı çalışmaları ile doğrudan ilgilidir. Bu yüzden göreli olarak daha kıt sermaye stokuna sahip bulunan gelişmekte olan ülkeler açısından, finans piyasalarının gelişimini hızlandırmak özel ve önemli çaba sarfı gerektirmektedir. Gelişmekte olan bir ülke konumundaki Türkiye de, finansal piyasaların en önemli aktörü bankalardır. Diğer yandan, 1985 yılında İstanbul Menkul Kıymetler Borsası (İMKB)'nın kurulmasıyla başlatılan sermaye piyasalarını geliştirme yönünde ciddi çabalar sarf edilmiş, derinliğin artırılması amacıyla özellikle 2010 sonrası dönemde Borsa İstanbul A.Ş. (BİAŞ)' in kurulması, altın bankacılığı, kira ve altın sertifikalarının geliştirilmesi gibi önemli yapısal düzenlemeler gerçekleşmiştir.

Finansal piyasaların, gelişmiş tüm dünya ülkelerinde olduğu gibi Türkiye'de de en önemli öğesi, bankalardır. Bankalar, yatırımcılara başta ellerindeki küçük-büyük her tür tasarrufu belli bir faiz karşıllı̆ında 'mevduat' olarak toplama ve yine belli bir faiz karşıllı̆ında 'kredi' olarak kullandırma alternatifi sunan finansal kurumlardır. Bunlar, yatırımc tercihinde, tüm ülkelerde genelde ilk siralarda yer alır. Finans piyasalarında önemli bir başka ürün, 'menkul değer yatırımları'dır. Bu konuda, Türkiye'de örgütlenmiş ilk kurum, İstanbul Menkul Kıymetler Borsası olup, yeni adı Borsa İstanbul'dır. Başlangıçtan bugüne oldukça inişli ve çıkışlı seyir izleyen menkul kıymetler borsası, dönem dönem yatırımc1sına önemli kazançlar sağlamasına karşılık, özellikle küçük tasarruf sahiplerine daha fazlasıyla kayıplar yaşatmıştır. 
Menkul kıymet piyasalarındaki işlem hacmi göstergesi, finansal piyasaların gelişmesi ve derinleşmesi açısından önemli bir gösterge olarak kabul edilir. Diğer yandan, bu gösterge banka mevduat ve kredi hacmi ile gayri safi yurt içi hasılası arasında pozitif yönlü bir ilişkiden söz edilebilir. Nihayet, kişilerin milli gelirden aldıkları pay artıkça, nisbi olarak tasarruf olanakları da artar. Yanı sıra, piyasalar derinleştikçe menkul değer yatırımı tercihleri de artacaktır. Ancak, özellikle yaklaşık son yirmi yılda, bu üç göstergede önemli gelişmeler yaşanmasına karşıllı, İMKB işlem hacminde ülke ekonomisinin büyüklügü ile uyumlu bir ölçeğe ve derinliğe ulaşılamamıştır. 2000'li yılların başlarında borsadaki yatırımcı sayısı 600 bin seviyesinden 1 milyon 500 bine kadar yükselmiştir. 1998'deki Asya Krizi ve ardından yaşanan Rusya Krizi ile 1850 seviyelerine kadar düşen borsa 100 endeksi 1999 yılının sonunda 15 bin 250 seviyesinden kapand1. 2000 yılının hemen başında 20 bin seviyesinin üzerini gören endeks o günlerden başlayarak Eylül 2001'e kadar yeniden 7100 seviyelerine kadar düştü. 2003 yılının sonlarına gelindiğinde ise hala 15 bin seviyelerindedir (Erdinç, 2004, s.6). Bugün ise, durum bundan farkl1 değildir. Örneğin, 2019 yılı Mart sonu itibarıyla Borsa İstanbul'daki toplam yatırımcı sayısı 1 milyon 170 bin 725'tir (Merkezi Kayıt İstanbul, 2019: 10). Yatırımcı sayısı, yaklaşık yirmi yıl öncesine göre, geridedir. Birçok nedeni olmasına karşıllı, en önemli nedenlerinden biri, özellikle küçük bireysel yatırımcıların inişli çıkışlı/dalgalı, spekülasyonların yoğunlaştığı dönemlerde ciddi kayıplara uğraması, borsadan uzaklaşmasıdir

$\mathrm{Bu}$ çalışmada, finansal piyasaların istikrarı ve gelişmesi açısından temel finansal gösterge olan banka mevduat ve kredi hacmi ile araştırma dönemini kapsaya ismiyle İstanbul Menkul Kıymetler Borsası işlem hacmi ve bütün bu temel göstergelerin ardındaki temel gösterge gayrisafi yurt içi hasıla (milli gelir) arasındaki etkileşim, 2002-2011 dönemi verileri ışığında incelenmiştir. Dönemin tercih edilmesinde, yatırımcıların borsadan uzaklaşmasına neden olan yoğun ve çok ciddi siyasi, ekonomik, sosyal, hatta doğal sarsıntıların yaşanmış olması etkili olmuştur. Bunlardan birkaçı aşağıdadır;

Türkiye, 2000'li yıllara önce iki büyük (17 Ağustos 1999 Gölcük ile ardından 12 Kasım 1999-Düzce'de yaşanan) depremle girmiştir. Bazı kaynaklarda farklı olmakla birlikte çok sayıda (resmi rakamlara göre 18 bin 
civarında) can kaybı ve belirlenemeyen tutarda ekonomik kayıp yaşanmiştır.

Aynı dönemde, ülke 90'lı yıllardan intikal eden büyük ekonomik krizlerle uğraşmak zorunda kalmıştır. Henüz, bu krizler giderilmeden özellikle bankacılık sektöründen kaynaklanan Kasım 2000 ve Şubat 2001 Krizleri patlak vermiştir. Yirmiden fazla bankanın batmasıyla sonuçlanan süreç, sektörün yeniden yapılandırılması zorunluluğunu getirmiş, ancak tahribatın toplam maliyeti o günün milli gelirinin $1 / 3^{\prime}$ ünü aşarak 53,6 milyar dolara çıkmıştır (BDDK, 2010, s.57).

2002'in sonlarında yeni bir dönemin eşiğinde gerçekleşen seçim sonucunda iktidar değişmiş ve AK Parti hükümet kurmuştur. 2007'de Cumhurbaşkanlığı Seçim dönemi oldukça çalkantılı geçmiştir. Dönemin Genelkurmay Başkanı 27 Nisan'da bir bildiri yayımlayarak seçime müdahale yapmaya teşebbüs etmiş, ancak iktidarın kararlı duruşu sonucu teşebbüs geri tepmiştir.

Yurt içinde bunlar yaşanırken, dışarda da önemli gelişmeler ortaya çıkmıştır. 1980'lerden önce bilinmeyen tezgahüstü türev ürünler 2006'ya gelindiğinde 400 trilyon doları aşarak (Ferguson, 2011, s.11) dünyadaki varlıkları defalarca satınalmaya yetecek düzeye ulaşmış, 2007'ye gelindiğinde ise bu dayanılmaz şişkinlik Amerika'da Mortgage Krizi olarak patlak vermiştir. Öyle ki, süreç, o kadar hızlı yayılmış kısa zamanda (2008) tüm dünyayı sarmış ve 2009'da büyük durgunluğa dönüşerek Küresel Finansal Kriz halini almıştır. Gelişmiş ülkeler, başta Avrupa ülkeleri olmak üzere büyük daralmalar ve sosyal çalkalanmalar yaşanmıştır. Nihayet, bu daralmalar Türkiye'ye diş ticaretteki en önemli pazarı olan Avrupa ülkeleri üzerinden az çok yansımıştır. Ancak, bütün bu olumsuz konjonktüre karşın, dönem ekonomik açıdan başarılı geçmiştir.

\section{Literatür Özeti}

Türkiye'de banka mevduat ve kredileri ile gayrisafi yurtiçi hasıla, ekonomik büyüme ilişkisinin araştırıldığı çok sayıda çalışma yapılmıştır. Yanı sıra, bu çerçevede istihdam ilişkisi gibi sektörel ilişkilerin araştırıldığı çalışmalar da vardır. Ancak, menkul kıymetler borsasında gerçekleşen işlem hacmini kapsayan çalışmaya pek rastlanılmamıştır. Yapılan çalışmalarda, konu benzerliği yanında, kullanılan istatistik model ve 
testler arasında da benzerlik dikkat çekmektedir. Bunlardan bir kısmına aşağıda değinilmiştir.

Türkiye ekonomisinin enflasyon, milli gelir, döviz kuru, para arzı ve faiz oranları değişkenlerine ait 1987: 01-2002: 04 dönemine ait üçer aylık veriler kullanılarak yapılan bir çalışmada, söz konusu değişkenler arasındaki ilişki VAR model ile incelenmiştir. Analiz sonuçlarına göre faiz oranının hem döviz kuru, hem para arzı, hem de enflasyonu etkileyen kritik bir değişken olduğu, para arzının enflasyonu doğrudan, döviz kurunun ise dolaylı olarak etkilediği sonucuna ulaşılmıştır. Var modelden elde edilen varyans ayrıştırması sonuçlarına göre, enflasyonu en çok etkileyen iki değişken döviz kuru ve faiz oranı olarak tespit edilmiştir. Etki-tepki fonksiyonları sonuçlarına göre faizleri kontrol etmenin döviz kurunu sabitlemeye oranla daha uygun bir enflasyonla mücadele arac1 olabileceğine işaret edilmektedir. Yazar, bu bulgunun döviz kurunu çıpa olarak kullanan istikrar programlarının uygulandıkları ekonomilerde makro dengeleri etkileyen krizlerle sonuçlanmış olması deneyimiyle uyum içinde olduğunu vurgulamaktadır (Işık, 2005, s.341).

Türkiye ekonomisinin 1990-2003 yıllarını kapsayan dönemdeki kamu açıklarının, temel ekonomik değiş̧kenler üzerinde oluşturduğu makroekonomik etkilerinin incelendiği bir çalışmada, kamu bütçe açıklarının makro etkilerini test etmek amaciyla model kurulmuş ve vektör otoregresyon analizi yöntemi kullanılmıştır. Yapılan uygulamada 1990-2003 yılları arasında bütçe açıklarındaki artıştan çeşitli yönlerde etkilendiği sonucuna varılmıştır. Milli gelir; bütçe açığı, faiz farkı, döviz kuru ve cari işlemler açı̆̆ı değişkenlerindeki artıştan olumlu etkilenmiştir. Bu değişkenlerdeki değişiklikler milli geliri arttırıcı olmuştur. Analiz sonucuna göre, milli gelir M2 değişkeninden ters yönde etkilendiği görülmüştür (Direkçi, 2006, s.134).

14.03.2008 tarihinde iktidardaki Ak Parti'ye karşı açılan ve 30.07.2008 tarihinde sonuçlanan kapatma davasının Türkiye riski üzerine etkisi VAR model kullanılarak bir çalışmada belirlenmeye çalışılmıştır. Bloomberg'den temin edilen, 02.01.2004-30.07.2009 tarihleri arasında yer alan ve günlük verilerden oluşan 1444 adet veri ile Türkiye'nin 5 yıllık spreadleri, Dow Jones Endeksi, 2030 vadeli Türkiye gösterge Eurobondu'nun faizi, Türkiye yurtiçi gösterge faizi, İMKB 100 Endeksi Volatilitesi ile açılan kapatma davası için kullanılan kukla değişkenlerin 
etkileşimi araştırılmış, Granger nedensellik testi sonuçlarına göre, gösterge faiz ile İMKB volatilitesi; Dow Jones Endeksi ile yurtdışı piyasalarda işlem gören 2030 vadeli gösterge Türkiye eurobondu; Türkiye 5 yıllık CDS spreadindeki değişimler arasında ve Türkiye CDS'i ile Dow Jones ve 2030 vadeli gösterge Türkiye eurobondun değişkenleri arasında Granger nedenselliği tespit edilmiştir. Sonuç olarak davayı temsil eden kukla değişkenin Türkiye CDS spreadleri üzerinde istatistiksel olarak anlamlı bir etkisinin olmadığ 1 ve Türkiye CDS spreadlerini etkileyen en önemli iki değişkenin Dow Jones Endeksi ve 2030 vadeli Türkiye gösterge eurobond faizi olduğu belirlenmiştir (Ersan ve Günay, 2009, s.21).

Türkiye ekonomisi için Taylor Kuralı'nın geçerliliğinin test edildiği bir çalışmaya döviz kuru da dahil edilerek genişletilmesi suretiyle gelişmiş ülkeler için geçerli olan Taylor Kuralı'nın Türkiye için geçerliliği 'Genişletilmiş Taylor' bilgi setini oluşturan değişkenler kullanılarak araştırılması amaçlanmıştır. Çalışmada mevcut literatürden farklı olarak Taylor Kuralı'nın geçerliliği çeşitli faiz oranlarına göre model denemeleri yapılarak test edilmiştir. Bu amaçla, araştırmada 1986:5-2010:9 dönemini kapsayan aylık veriler kullanılarak VAR yöntemiyle analiz yapılmıştır. Sonuç olarak; Türkiye'nin para politikası aracı olarak MB'nın kısa vadeli krediler için öngördüğü reeskont faiz oranı temel alınarak yürütüldügünde Taylor Kuralı kapsamında beklentiler daha uygun sonuçlar ortaya konulabileceği tahmin edilmiştir. Bir para politikası aracı olarak reeskont faiz oranı kısa vadeli faiz olarak alınması durumunda Taylor Kuralı'nın geçerli olduğu sonucuna varılmıştır (Lebe ve Bayat, 2011, s.95-112).

Türkiye'de banka kredi kanalının işleyişini VAR model yardımıyla analiz etmek için yapılan bir çalışmada 1990:01-2008:11 dönemi aylık M2 para arzı, bankalararası gecelik faiz oranı, mevduat bankaları toplam mevduatları, mevduat bankaları toplam kredileri, sanayi üretim endeksi, tüketici fiyat endeksi ve mevduat bankaları toplam menkul kıymet portföyleri değişkenleri verileri kullanılmıştır. Analiz sonuçlarına göre, para politikası değişkeni olarak gecelik faiz oranları seçildiğinde banka kredi kanalının etkin çalışmadığı sonucuna varılmıştır. Para politikası şokundan sonra banka kredi kanalıyla sanayi üretiminin başlangıç döneminde aynı yönlü tepki vermiş olması teoriye uygun bir şekilde gerçekleştiği, ancak bu dönemden sonra sanayi üretiminin banka kredilerinden 
bağımsız olarak dalgalanması bağımlılık ilkesinin geçerliliğini kuşkulu duruma düşürdüğü belirtilmiştir. Para politikası değişkeni olarak M2 para arzı tercih edildiğinde ise banka kredi kanalının etkin çalıştı̆̆ına ilişkin bulgulara ulaşılmıştır. Bağımlılık ilkesinin etkin çalışmasına bir kanıt olarak para politikası şokundan sonra toplam kredilerle toplam sanayi üretiminin eşanlı daralması gösterilmiştir. Sonuçta, para politikası değişkeni olarak para arzı, gecelik faizle karşılaştıııldığında, daha etkin bir politika değişkeni olduğu bilgisine ulaşılmıştır (Peker, Canbazoğlu, 2011, s.139).

Türkiye'de mevduat, banka kredileri ve ekonomik büyüme arasındaki karşılıklı etkileşimin araştırıldığı bir çalışmada 1998:1- 2012:1 dönemine ait üçer aylık veriler kullanılmıştır. Kredi, mevduat ve ekonomik büyüme arasındaki nedensellik ilişkisi Granger Nedensellik Testi ile araştırılmıştır. Çalışmadan elde edilen bulgular, mevduatlardan hem ekonomik büyümeye hem de kredilere doğru, ekonomik büyümeden ise kredilere doğru bir nedensellik ilişkisinin olduğunu göstermiştir (Vurur, Özen, 2013, s.117-131).

Mevduat bankaları yurtiçi kredi hacmi ile gayri safi yurtiçi hasıla arasındaki ilişki 1998-2012 dönemi üçer aylık verileri kullanılarak analiz edilen bir çalışmada, yapısal kırılmaya izin veren Zivot-Andrews birim kök testi, Gregory-Hansen eşbütünleşme testi ve Granger nedensellik testi kullanılmıştır. Yapılan analizler neticesinde, her iki serinin birinci mertebeden durağan olduğu ve aralarında uzun dönem ilişkisinin bulunmadığı sonucuna ulaşılmıştır. Uygulanan Granger nedensellik testi sonrasında ise iki seri arasında bir nedensellik ilişkisi bulunmamıştır (Tuna, Bektaş, 2013, s.139).

Yurtiçi kredi hacminin ekonomik büyüme üzerindeki etkisi 1992-2011 dönemi üç aylık verileri kullanılarak Sınır Testi yaklaşımıyla yapılan bir araştırmadan elde edilen ampirik kanıtlara göre, değişkenler arasında eşbütünleşmenin olduğu tespit edilmiştir. Buna göre, uzun dönem analizinde kredi hacminin ekonomik büyüme üzerindeki etkisi teorik beklentilerle uyumlu bir şekilde pozitif ve istatistiki olarak anlamlı bulunmuştur. Kısa dönem analizinde ise hata düzeltme teriminin katsayısı istatistiki açıdan anlamlı ve negatif bulunmuştur. Dolayısıyla değişkenler arasında ortaya çıkan sapmalar uzun dönem denge düzeyine 
yakınsamaktadır. Nedensellik testinde kredi hacmi ve ekonomik büyüme arasında çift yönlü ilişki tespit edilmiştir (Mercan, 2013, s.54).

Türkiye'de bankacılık sektörü toplam kredi hacminin, istihdam ve ekonomik büyüme üzerindeki etkileri, Carrion-i-Silvestre vd. (2009) çoklu yapısal kırılmalı birim kök testi, Maki (2012) çoklu yapısal kırılmalı eşbütünleşme testi ve dinamik en küçük kareler yöntemi yardımıyla inlenmiştir. 2000:Q1-2012:Q4 dönemi verileri kullanılarak yapılan analiz sonucu, Türkiye'de kredi hacmindeki artışların istihdamı ve ekonomik büyümeyi pozitif etkilediği tespit edilmiştir (Göçer vd., 2015, s.65).

Ekonomik büyümeyi etkileyen ekonomik faktörler içinde bankacılık sektörünün yeri önemlidir. Başta, para politikaları ve parasal kontrol için bir kanal olmak yanında, ekonominin yeniden yapılanmasında ve uzun dönemli sürdürülebilir makroekonomik istikrarın sağlanmasında etkili bir araçtır. Bu yaklaşımdan hareketle yapılan bir çalışmada, Türkiye ekonomisi özelinde bankacılık sektörü ile ekonomik büyüme arasındaki ilişki araştırılmıştır. Çalışma, Granger nedensellik ve Eşbütünleşme modeli ile gerçekleştirilmiş ve Türkiye ekonomisine ait 2003:Q1-2013:Q4 arasındaki zaman serisini kapsayan GSYİH ile banka kredilerine ait üçer aylık veriler kullanılmıştır. Elde edilen bulgular, bankacılık sektöründen ekonomik büyümeye doğru nedensellik ilişkisini ortaya koymuştur. Bankacılık sektörünün ekonomik büyümenin belirleyicisi olabileceği, etkin bir araç olarak kullanılabileceği belirlenmiştir (Turgut ve Ertay, 2016, s.114-128).

Finansal gelişme ile büyüme arasındaki ilişki üzerine yoğunlaşan araştırmaların önemli bir bölümünde banka kredilerindeki genişlemenin ekonomik büyümeyi tetiklediği belirlenmiştir. Ancak, ekonomik büyümenin banka kredi hacmini artırıcı yönde etki yarattığını iddia eden iktisatçılar da vardır. Bunlar, banka kredileri ile ekonomik büyüme arasındaki nedensellik ilişkisinin yönü hakkında farklı düşünmektedirler. Bu düşünceden hareketle yapılan bir çalışmada, banka kredileri ile ekonomik büyüme arasındaki ilişki Eşbütünleşme ve Nedensellik analizleri çerçevesinde 2002:1 ile 2016:4 dönemi verileri kullanılarak incelenmiştir. Çalışma sonuçlarına göre banka kredi hacmindeki genişleme ile ekonomik büyüme arasında çift yönlü bir nedensellik ilişkisi bulunmaktadır (Karahan vd., 2018, s.25). 
Türkiye için 2003Q1-2017Q4 arasındaki döneme ait çeyreklik veriler kullanılarak finansal gelişmenin ekonomik büyüme üzerindeki etkisini incelemek amacıyla yapılan bir çalışmada finansal gelişme göstergesi olarak yurtiçi kredi hacmi kullanılırken ekonomik büyüme göstergesi olarak reel gayrisafi yurtiçi hasıla kullanılmıştır. Çalışmada birim kök testleri, Johansen eşbütünleşme testleri ve Granger nedensellik analizinden yararlanılmıştır. Analiz sonuçlarında, yurtiçi kredi hacmi ile ekonomik büyüme arasında uzun dönemli bir ilişkinin olduğu ve yurtiçi kredi hacminden ekonomik büyümeye doğru tek yönlü bir nedenselliğin olduğu tespit edilmiştir (Kılıç, 2018, s.1036).

\section{Analiz Konusu Finansal Göstergeler}

Çalışma kapsamındaki finansal göstergeler üzerine açılamalar aşağıdadır.

\section{Banka Kredileri}

Banka kelime anlamı olarak İtalyanca kökenli olup "sıra, tezgah" anlamına gelen "Banco" kelimesinden türemiştir (Yetiz, 2016, s.5). Genel anlamıla bankalar, fon talep eden kesimi fonları kanalize eden yatırım fırsatları yaratan ve finansal sistem ile ekonomisinin etkinliğini sağlamada önemli roller üstlenmiş finansal piyasa kurumları olarak kabul edilmektedir. Bir ticari bankayı diğer mevduat kurumlarından farklı kılan yönü, ticari bankaların sahibinin veya sahiplerinin isteği üzerine üçüncü kişilere vadesiz mevduatlar sunabilme özelliğidir (Uludağ ve Arıcan, 2001, s.200). Bu mevduatlar, bankanın karını maksimize etmesi için yönetilmesi gereken yükümlülükler olurken, mevduatların borç (kredi) olarak verilmesi suretiyle oluşan varlıkların da yönetilmesi gerekir. Dolayısıyla, bankaların temel faaliyet alanına uygun olarak mevduat sahipleri ve borç alanlar arasında aracı olarak hareket etmeleri oluşturmaktadir (Heffernan, 2005, s.1).

Tanımda ifade edildiği üzere, bankaların en temel faaliyetlerinden biri olan kredi, herhangi bir kişi veya kuruma para vermek ya da parasını sonra almak kaydıyla ona mal vermeyi kabul etmek ya da alınacak bir mal, yapılacak bir hizmetin yerine getirilmesine kefalet etmek, garanti 
etmek şeklindeki uygulamadır (Parasız, 1997, s.173). Plasman olarak da tanımlanan 'kredi'nin oluşması için kredi kullanan(borçlu), kredi veren(alacaklı), devredilen satın alma gücü veya verilen garanti(kefalet), süre(vade), güven ve saygınlık (itimat ve itibar), risk, teminat (garanti) ve gelir gibi öğelere sahip olması esastır. Bankaların en önemli ve temel gelir kaynağı, kredilerdir. Bankalar zaman zaman 'kredi' kaynaklı ciddi rekabete girebilmektedirler. Bu rekabet, kredi çeşitlerini çoğaltma veya faiz oranlarını düşürme yönlü olabilmektedir. Ancak bankalar kredi verirken belirli prensiplere ve prosedürlere bağlı kalmaktadır. Bu prensip ve prosedürler, sigorta, dokümantasyon standartları ve güvenlik, problemli kredilerin geri alınması, kanuni kısıtlamalar ve uyum, kredi fiyatlama, müşterilerin finansal bilgileri ve kredilerin yeniden değerlendirilmesi olarak ifade edilmektedir (Şakar, 2011, s.7).

2000'li yılların başlarında yaşanan 'finansal kriz'le birlikte, büyük kayıplar yaşayan bankacılık sektöründe 'yeniden yapılanma' gündeme gelmiş, ciddi reformlar gerçekleşmiş ve önceki dönemlere nazaran 2010'a gelindiğinde oldukça güçlü bir yapı ortaya çıkmıştır. Bu süreçte, çok önemli yabancı sermaye girişi olmuş ve finansal sektörün gelişmesi yönünde katkı sağlanmıştır (Karacaoğlan, 2011, s.113).

\section{Mevduat Hacmi}

Banka plasmanları, yani kredileri için en önemli kaynak olan mevduat, bankalara istendiği zaman veya belirli bir sürenin sonunda, geri alınmak düşüncesiyle yatırılan para ve çeklerdir. Buna karşılık, mevduat sahiplerine de "mudi" denilmektedir. Parayı yatıran bu kişiler yatırdıkları para kadar bankadan alacaklı durumuna geçerler. Bankaların, faaliyetlerini yürütmede kullandıkları temel kaynak, topladıkları mevduatlardır. Bu kaynak veya fonları kullanarak ihtiyaç sahiplerine kredi açarlar. Kredi faizi ile daha düşük olan mevduat faizleri arasındaki fark, bankanın esas faaliyet kazancını oluşturur.

Gerçek ve tüzel kişiler, sınırlı da olsa gelir ve servetlerinin bir kısmını en likit araç olan ve kullanılma serbestliği sağlayan nakit para olarak yanlarında tutmayı tercih ederler, büyük kısmını ise cari yada vadeli mevduat şeklinde bankalarda tutarlar. Böylece, bir yandan çalınma ve 
kaybolmaya karşı korunurken yanı sıra karpayı/faiz geliri sağlanması da mümkün olur.

Aşağıdaki tabloda Türk Bankacılık Sistemi'nde yer alan bankaların toplam mevduat ve kredilerinin 2002-2011 arası değişimi yer almaktadır.

Tablo 1: 2002-2011 Dönemi Türk Bankacılık Sistemi'ndeki Mevduat ve Kredi Gelişimi (1.000.-TL)

\begin{tabular}{llllll}
\hline Yillar & Mevduat & Artış & Kredi & Artış & Kredi/Mevduat \\
\hline 2002 & 145.594 & - & 54.860 & - & 0,38 \\
\hline 2003 & 164.923 & 0,13 & 72.169 & 0,32 & 0,44 \\
\hline 2004 & 203.385 & 0,23 & 107.615 & 0,49 & 0,53 \\
\hline 2005 & 261.948 & 0,29 & 160.005 & 0,49 & 0,61 \\
\hline 2006 & 324.069 & 0,24 & 228.141 & 0,43 & 0,70 \\
\hline 2007 & 371.927 & 0,15 & 293.928 & 0,29 & 0,79 \\
\hline 2008 & 472.695 & 0,27 & 384.417 & 0,31 & 0,81 \\
\hline 2009 & 522.415 & 0,11 & 418.684 & 0,09 & 0,80 \\
\hline 2010 & 631.119 & 0,21 & 554.128 & 0,32 & 0,88 \\
\hline 2011 & 695.501 & 0,10 & 682.900 & 0,23 & 0,98 \\
\hline
\end{tabular}

Kaynak: http://ebulten.bddk.org.tr/AylikBulten/Basit.aspx, Erişim: 05/10/2018

Tabloda, dikkat çeken önemli nokta, 2001 krizi sonrası başlayan 'yeniden yapılanma' süreci" sonrasında, yeni sağlıklı bir yapıya kavuşmuş olduğudur. Kriz öncesi 81'e kadar ulaşan banka sayısı, 2011'e gelindiğinde 48 'e inmiştir. Buna karşılık, tüm makro göstergelerde (kredi ve mevduat gibi) olduğu gibi aktiflerde 133.5 Milyar TL.'den 2012 Ocak ayında 1.213.7 Milyar TL.'ye doğru yükselmiştir. Ancak, daha önemlisi, 2002'lerde mevduatın yarısından daha azı krediye dönüşürken, 2011 sonunda neredeyse yüzde 100'e yaklaşarak, bankaların esas işine, aracılık fonksiyonlarına döndügünü göstermektedir (Tiryaki, 2012, s.161).

$\mathrm{Bu}$ arada, bankacilık sistemi, yine 'yeniden yapılanma süreci'nin olumlu etkisiyle, dış dünyaya açılmış ve çok sayıda yabancı yatırımcı talebiyle karşılaşmıştır. Bunlardan bir kısmı gerçekleşmiş ve 2005 yılında Türkiye'de yerleşik olmayanların 'halka arz edilmeyen ödenmiş sermaye'deki payları \%14,6 iken, 2012 sonunda \%27,8 olarak gerçekleşmiştir. Diğer yandan, 'halka arz edilen' yaklaşık \%15 oranındaki banka sermaye hisselerinin de, İMKB'nin diğer hisselerinde olduğu 
gibi önemli kısmının yabancı yatırımcıların portföyünde olduğu bilinmektedir (TBB, 2013: 260). Yine, yabancı bankaların, bankacılık sistemi toplam aktifleri içindeki payı 2002 yılında \%3,11 iken, 2010 Eylül'ünde \%13,7'ye yükselmiştir (Karacaoğlan, 2011, s.81).

\section{IMKB İşlem Hacmi}

Borsa, alıcı ve satıcıların ekonomik varlıkların alım satımını yapmak üzere toplandıkları ve hükümet denetimi altındaki piyasadır. Borsada işlem görecek mal ya da ekonomik varlıkların bazı özelliklere sahip olmaları gerekmektedir. Bu özelliklerin başında belirli standartlara ayrılabilmesi, homojen nitelikte olması ve büyük miktarlarda sağlanabilme özellikleri gelmektedir. İşlem görecek malların borsada bizzat bulundurulması gerekmemektedir. İşlemler genellikle örnek miktarlar üzerinden yapılmaktadır. Borsada işlem gören ekonomik varlığın (mal, menkul değer, döviz) belirli bir günde veya anda piyasadaki arz ve talep güçlerine göre oluşan fiyatına 'piyasa değeri' denir (Ertuğrul, 2008, s.152).

İstanbul Menkul Kiymetler Borsası, Menkul Kıymetler Borsaları Hakkında 91 sayılı kanun hükmünde kararname uyarınca 1985 yılında kurulmuş, yetkilerini kendi sorumluluğu altında bağımsız olarak kullanan ve Sermaye Piyasası Kurulu'nun gözetim ve denetimi altında olan tüzel kişiliği haiz bir kamu kurum iken, 3 Mart 2013 tarihinde kurulan Borsa İstanbul A.Ş.'ne (BİAŞ) dönüşmüştür. Borsa İstanbul, resmi çalışma günlerinde faaliyette bulunmaktadır. BİAŞ aynı zamanda, bir meslek kuruluşu gibi üyeleri bulunmakta, işlem yapmaya da bunlar yetkilidir. Menkul kıymet borsalarında, en temel göstergeler, işlem hacmi, işlem miktarı ve işlem gören şirket sayısı ile bunların halka açıklık oranlarıdır. Bu göstergeler, borsaların en başta derinliği olmak üzere, şeffaflık, bilgi edinebilirlik, spekülasyondan uzak olmak gibi nitelikleri sağlar. İşlem miktarı, bir piyasada, bir seansta ya da belli bir dönemde alınıp satılan (el değiştiren) menkul kıymet adedidir. İşlem hacmi ise, gerçekleşen her sözleşmedeki işlem miktarı ile işlem fiyatının çarpılması sonucu bulunan hacimdir. Tüm payların işlem hacimleri toplamı, Pay Piyasası'nın toplam işlem hacmini oluşturur 
(https://www.borsaistanbul.com/data/kilavuzlar/Cevaplarla_Borsa_ve_S ermaye_Piyasasi.pdf, Erişim: 20/06/2019).

Borsadaki işlem hacmi, borsada bütün firmalara ait hisse senetlerinin belirli bir gündeki toplam alışveriş miktarını ifade etmektedir. Diğer bir ifadeyle, o gün borsada ne miktar para döndüğünü gösterir. İşlem hacmi borsadaki gelişmeleri ortaya koyan önemli göstergelerden biridir. Belirli bir günde borsanın ne kadar "sı̆̆" ya da "derin" olduğu, diğer göstergelerle birlikte, işlem hacminden anlaşılmaktadır. Menkul kıymetlerin alım satımında 'işlem hacmi' olarak çeşitli ölçüler mevcuttur. Bunlar;

- Kümülatif İşlem Hacmi; kumülatif işlem hacmi kullanılacak verinin yapısına göre haftalık, aylık veya yıllık olarak değişiklik göstermektedir. Örneğin, haftalık veriler ile çalışıldığında, hisse senedinin günlük işlem hacimlerinin toplamı alınır ve haftalık verilere ulaşılmış olunur.

- Devir Hızı; her bir hisse senedi için işlem görme oranını ifade etmektedir.

- Kümülatif Devir Hızı; günlük devir hızı değerinin toplanmasıyla haftalık, aylık veya yıllık veri yapıları kümülatif devir hızı olarak elde edilir.

- Toplam İşlem Hacmi; hisse senetleri için gerçekleşen işlemlerdeki her emrin içerdiği her bir hisse senedi sayısı ile her bir işlem fiyatının çarpılmasıyla elde edilen sonuçların toplamıdır.

- İşlem Sıklığı; hisse senedinin bir gün içinde yapılan alım satım sayısı işlemlerini ifade etmektedir.

- İşlem Yapılan Gün Sayısı; borsada bir yıl içinde resmi olarak işlem yapılan toplam gün sayısını ifade etmektedir.

- Tablo 2'de, 2002-2011 dönemi İMKB'nin toplam işlem hacmi ile bu yıllarda IMKB'de işlem gören şirket sayıları yılsonları itibarıyla yer almaktadır. 
Tablo 2: IMKB'de İşlem Gören Şirket Sayısı ve Toplam Yıllık İşlem Hacmi (20022011) (Bin TL.)

\begin{tabular}{llll}
\hline Ylllar & IMKB'de İşlem Gören Şirket Sayısı & IMKB İşlem Hacmi & Artıs \\
\hline 2002 & 288 & 106.301 & - \\
\hline 2003 & 285 & 146.642 & 0,37 \\
\hline 2004 & 297 & 208.413 & 0,42 \\
\hline 2005 & 304 & 269.931 & 0,29 \\
\hline 2006 & 316 & 325.151 & 0,20 \\
\hline 2007 & 319 & 386.681 & 0,18 \\
\hline 2008 & 317 & 332.614 & $-0,13$ \\
\hline 2009 & 315 & 482.534 & 0,45 \\
\hline 2010 & 331 & 635.664 & 0,31 \\
\hline 2011 & 368 & 695.337 & 0,09 \\
\hline
\end{tabular}

http://www.imkb.gov.tr, 25/01/2012, http://www.kap.gov.tr, Erişim: 25/10/2018

Tabloda dikkat çeken nokta, dönem boyunca borsada hisseleri işlem gören şirket sayısı fazla artmamış olmasına rağmen işlem hacmi artışı 2008 kriz yılı dışında istikrarlıdır. Öte yandan, özellikle son (2009 ve 2010) yıllardaki artış oldukça ümit verici görünmektedir.

\section{Gayri Safi Milli Gelir/Hasıla}

Çalışmada kullanılan bir başka değişken 'Gayrisafi Milli Hasıla'dır (GSYİH). Belirli bir dönem (genellikle 1 yıl) içinde ulusal bir ekonominin yarattı̆̆1 (nihai) mal ve hizmetler toplamının para ile ifadesi GSYİH'y1 verir (Alkin, 2009, s.53).

Türkiye'de milli gelir istatistikleri, 1950'li yılların başından bu yana düzenli olarak TÜiKK tarafından hazırlanıp yayımlanmaktadır. Söz konusu süre içerisinde Türkiye'de milli gelir istatistikleri üç kez güncellenmiştir. Bu güncellemelerin ilki 1973 yılında, ikincisi 1993 yılında, üçüncüsü ise 8 Mart 2008 tarihinde yapılmıştır. Ancak 2008 yılında yapılan güncellemede, geriye dönük düzeltmeler daha kısa tutulmuştur. Yeni milli gelir serisinde 1998 yılı temel yıl olarak alınmış, 1998 yılı öncesi için herhangi bir çalışma yapılmamıştır. Dolayısıyla 1998 yılı ile birlikte eski seri ile yeni seri arasındaki bağlantı kopmuştur.

Yeni milli gelir serisinde 1998 yılı sabit fiyatları kullanılmakta ve üretim bazında faaliyet kolları itibarılla katma değer büyüklükleri Nace 
Rev. 1 sinıflamasına göre verilmektedir. Ayrıca, söz konusu seride faaliyet kollar itibarıla katma değer büyüklükleri temel fiyatlarla hesaplanmaktadır. Temel fiyatlarla katma değer büyüklükleri, mal ve hizmet üretimi üzerinden alınan dolaylı vergileri kapsamamaktadır.

Türkiye ekonomisi, 2003 sonrası dünya konjonktürünün de desteği ile güçlü bir büyüme dönemine girmiştir. Makroekonomik istikrarı sürekli kılacak, ekonomiyi esnek, etkin ve üretken bir yapıya kavuşturacak yapısal reformlarla birlikte uygulamaya konulan sıkı para ve maliye politikaları, ekonomide güven ve istikrarı büyük ölçüde sağlamıştır. 2002-2007 döneminde yüksek büyüme oranları gerçekleşmiş, ihracatta ve üretimde yüksek oranlı artışlar sağlanmış, enflasyon oranları düşmüş, mali disiplin göreceli de olsa sağlanmıştır. Yapısal olarak büyüme dönemlerinde cari açığı da artan Türkiye ekonomisinde, kriz öncesi dönemde küresel likidite bolluğu sayesinde finansman sorunu yaşanmamıştır (Acar, 2013:17).

2001 krizi sonrasında, büyüme oranı 2002'de $\% 6,2,2003$ 'te $\% 5,3$ ve 2004 'te ise \%9,4 ile zirve yapmıştır. Daha sonra, 2005'te \%8,4 ile nispi bir yavaşlama eğilimi gösteren GSYİH büyüme oranı, 2006'da \%6,9'a, 2007 'de $\% 4,7^{\prime} y e$ ve 2008 'de de $\% 0,7^{\prime}$ ye gerilemiştir. Böylece, geçiş süreci olarak tanımlanabilecek 2003-2007 döneminde, yıllık ortalama \%6,9 gibi yüksek bir büyüme performansı yakalanmıştır. 2009'da ise, 2005'ten bu yana yapısal nedenlerin etkisiyle görülen nispi yavaşlamanın yanı sıra küresel krizin olumsuz etkilerinin de katkısıyla GSYİH \%4,8 oranında küçülmüş, Türkiye ekonomisi için zor bir yıl olmuştur. Kriz, finansal kaynaklı olsa da etkileri en çok reel sector üzerinde hissedilmiştir. Ancak Türkiye'nin 2001 yılında yaşadığ 1 kriz sonrasında uyguladığı yapısal reformlar, ülkenin kamu maliyesi ve bankacılık sektörü altyapısını güçlendirmiş, krizden daha sınırlı düzeyde etkilenmesini sağlamıştır (Acar, 2013, s.17).

GSYİH'daki bu büyüme, tabii olarak vatandaşların cebindeki paraya, dolayısıyla da sosyal yaşantısına yansımıştır. Fert başına milli gelir 2002 yılında sadece 3.529 dolar iken Cumhuriyet tarihinde ilk defa 2008 yılında 10.000 doların üzerine çıkmıştır (Babacan, 2010: 190). Fert başına milli gelirin artması, beraberinde vatandaşların hem tasarruf hem de (menkul veya gayrimenkul) yatırım yapma imkanlarının artması anlamına gelir. Diğer bir açıdan, bir ülkedeki milli gelirdeki büyüme, vatandaşların 
yapmış olduğu harcama, üretim, yatırım gibi temel ekonomik faaliyetlerdeki artışın bir ifadesi olduğundan, GSYİH değişkeni diğer değişkenlerin de değişik düzeylerde hem etkeni hem de edilgenidir.

Tabloda görüldüğü gibi, Türkiye, 2000'li yılların başında kendine özgü nedenlerden kaynaklanan kriz ile 2007 yılının sonlarında dış dünyadan kaynaklanan küresel finansal krize rağmen 2002-2011 dönemini 'parlak bir dönem' olarak geçirdiği açıktır.

Tablo 3. Gayri Safi Yurtiçi Hasıla - GSYİH (Cari ve Sabit Fiyatlarıyla)

\begin{tabular}{lllll}
\hline Yıllar & GSYİH (Cari) (Milyon TL) & Cari Büyüme (\%) & $\begin{array}{l}\text { GSYİH (Sabit) } \\
\text { (Milyon TL) }\end{array}$ & $\begin{array}{l}\text { Reel } \\
\text { Büyüme (\%) }\end{array}$ \\
\hline 2002 & 350.476 & - & 72.519 & - \\
\hline 2003 & 454.781 & 29.76 & 76.338 & 5.26 \\
\hline 2004 & 559.033 & 22.92 & 83.485 & 9.36 \\
\hline 2005 & 648.932 & 16.08 & 90.499 & 8.40 \\
\hline 2006 & 758.391 & 16.86 & 96.738 & 6.89 \\
\hline 2007 & 843.178 & 11.18 & 101.254 & 4.66 \\
\hline 2008 & 950.537 & 12.73 & 101.921 & 0.65 \\
\hline 2009 & 952.635 & 0.22 & 97.003 & -4.82 \\
\hline 2010 & 1103.750 & 15.86 & 105.885 & 9.15 \\
\hline
\end{tabular}

Kaynak: TüiK, Erişim: 20/12/2018

Çalışmanın bu kısmına kadar değişkenlerle ilgili genel bilgiler verilmiştir. Bundan sonraki kısmında finansal piyasaların istikrarı ve gelişmesi açısından önemli göstergeler olan milli gelir, banka mevduat ve kredi hacmi ile İMKB işlem hacmi arasındaki etkileşim incelenmiştir. Çalışma, 2002-2011 dönemi olup, konjonktür etkisini azaltmak amacıyla üçer aylık veriler kullanılarak yapılmıştır. Çalışmada kullanılan istatistiksel analiz yöntemi ise, vektör otoregresif(VAR) modelidir. Model hakkında kısa bilgi aşağıdadır.

\section{Çalışmada Kullanılan Ekonometrik Yöntemler}

Çalışmada, zaman serileri analizlerinde önemli bir konu olan değişkenlere ait zaman serilerinin durağan olmaları, yani birim kök içermemeleri özelliği, birim kök testi ile belirlenmiştir. Ardından, dönemde ortaya çıkan yapısal değişikliklerin testi yapılmıştır. Nihayet, analiz Vektör 
Otoregresyon (VAR) Modeli ve Granger Nedensellik Testi kullanılarak tamamlanmıştır. Yöntemler hakkında kısa bilgi aşağıda verilmiştir.

\section{Birim Kök Testleri}

Zaman serileri analizlerinde dikkat edilmesi gereken en önemli konulardan bir tanesi, ele alınan değişkenlere ait zaman serilerinin durağan olmaları, bir başka deyişle birim kök içermemeleri özelliğidir. Serilerin birim kök içerip içermedikleri çeşitli testlerle tespit edilmektedir. Ancak literatürde yaygın olarak kullanılan birim kök testleri Dickey ve Fuller (Dickey ve Fuller, 1979, s.427-431) tarafından geliştirilmiş Genişletilmiş Dickey-Fuller (ADF) testi ve Phillips-Perron tarafından geliştirilen (Phillips ve Perron, 1988, s.335-346) (PP) Birim kök testidir. Her iki test de literatürde yaygın olarak kullanılıp teorik bilgi kaynağının geniş olduğu için bu çalışmada testlere ait teorik bilgi verilmemiştir.

\section{Zivot-Andrews (ZA) Yapisal Kinlma Testi}

1929 Büyük Buhranının ve 1973 Petrol Krizinin ekonomide önemli yapısal değişikliklere neden olduğunu saptayan Perron (1989, 1990), bu amaçla yapısal değişiklikleri göz önünde bulunduran alternatif bir birim kök testi geliştirmiştir. Perron'un geliştirdiği yönteme göre ekonomide gerçekleşen yapısal değişiklikler önceden bilinmektedir. Zivot ve Andrews (1992), Perron'un test istatistiğini farklı şekilde ele almışlardır. Perron, ekonomide gerçekleşen kırılmayı dışsal olarak almakta ve önceden bilindiğini varsaymaktadır. Zivot ve Andrews dişsallık varsayımı sorgulamışlar ve yerine yapısal kırılmanın tam olarak bilinmediği durumu ya da yapısal kırılmanın içsel olarak gerçekleştiği durumu incelemişlerdir. Zivot ve Andrews, bu amaçla yapısal kırılmayı test edebilmek için üç farklı birim kök testi geliştirmiştir (Korkmaz ve Çevik, 2008, s.157-178) :

$$
\Delta y_{t}=\mu^{A}+\theta^{A} D U_{t}(\lambda)+\beta^{A} t+\alpha^{A} y_{t-1}+\sum_{j=1}^{k} c_{j}^{A} \Delta y_{t-j}+e_{t}
$$


$\Delta y_{t}=\mu^{B}+\beta^{B} t+\gamma^{B} D T_{t}^{*}(\lambda)+\alpha^{B} y_{t-1}+\sum_{j=1}^{k} c_{j}^{B} \Delta y_{t-j}+e_{t}$
$\Delta y_{t}=\mu^{C}+\theta^{C} D U_{t}(\lambda)+\beta^{C} t+\gamma^{C} D T_{t}^{*}(\lambda)+\alpha^{C} y_{t-1}+\sum_{j=1}^{k} c_{j}^{C} \Delta y_{t-j}+e_{t}$

Olası kırılma yılı olan $T \lambda$, Denklem (3.1)'de $T \lambda<t$ ise $\mathrm{DU}_{\mathrm{t}}(\lambda)=1$, diğer durumlarda sıfır değerini alan kukla değişkendir. Benzer şekilde Denklem (3.2)'de $t>T \lambda$ ise $\mathrm{D}^{*}(\lambda)=t-T \lambda$, diğer durumlarda sıfır değerini alan kukla değişkeni temsil etmektedir. Denklem (3.1) sabitte kırılmayı, Denklem (3.2) trendde kırılmayı ve son olarak Denklem (3.3) sabit ve trendde kırılmayı incelemektedir. Test uygulanırken, gözlem dönemindeki her bir yıl olası kırılma yılı olarak alınarak kukla değişkenler oluşturulup, $\alpha$ katsayısının $\mathrm{t}$ istatistikleri elde edilmektedir. Bütün gözlem dönemlerinin tümü için uygulandıktan sonra $\alpha$ katsayısının $\mathrm{t}$ istatistiğinin minimum elde edildiği yıl olası kırılma yılı olarak belirlenmektedir. Elde edilen $\mathrm{t}$ istatistikleri mutlak değerce kritik değerden büyükse serinin yapısal kırılmayla birlikte durağan olduğunu belirten alternatif hipotez kabul edilir.

\section{Vektör Otoregresyon (VAR) Modeli}

Eşanlı denklem sistemlerinde eleştirilen belirlenme probleminin ortadan kaldırılması için Sims (Barışık ve Çevik, 2010, s.162-164) tarafından geliştirilen VAR model, bütün değişkenlerin ilk etapta içsel olarak kabul edildiği bir modeldir. Sims, eşanlı modelleri belirlemenin sağlanması için çoğu kez değişkenlerin içsel-dışsal ayrımı ve parametreler üzerinde kısıtlama koymada keyfi davranıldığı konusunda eleştirerek, bütün değişkenlerin içsel olarak kabul edildiği VAR modeli geliştirmiştir (Granger, 1969, s.424-438).

VAR modelleri, yapısal model üzerinde herhangi bir kısıtlama getirmeksizin dinamik ilişkileri verebilmekte ve bu sebeple zaman serileri için sıklıkla kullanılmaktadır (Davidson ve MacKinnon: 1999, s.585). Modelin diğer avantajları ise, hangi değişkenin içsel (endogenous) hangisinin dişsal (exogenous) değişken olduğu şeklinde ön bir varsayıma ihtiyaç duymaması, böylece verilerin daha fazla özelliğinin yakalamasını 
sağlayarak çok zengin bir yapı sunarken, geleneksel yapısal modellerden daha iyi tahmin yapmasıdır (Brooks, 2008, s.291-292 ). İçsel/endojen değişken, değeri modelin içerisinde belirlenip açılanırken, dışsal/egzojen değişken, değeri modele dişarıdan verilen değişken olarak tanımlanır.

g değişkenli, p gecikme sayılı VAR modelinin genel matematiksel notasyonu aşağıdaki gibidir:

$$
\mathbf{Y}_{\mathbf{t}}=\boldsymbol{\alpha}+\sum_{\mathbf{j}=1}^{\mathrm{p}} \mathbf{Y}_{\mathbf{t}-\mathbf{j}} \Phi_{\mathbf{j}}+\mathbf{U}_{\mathbf{t}}
$$

(1) numaralı eşitlikte $Y_{t}(1 \times g)$ boyutlu değişken vektörü, $\alpha(1 \times g)$ boyutlu sabit terim, $\boldsymbol{\Phi}_{\mathrm{j}} \mathrm{j}=1,2, \ldots, \mathrm{p}$ için (gxg) boyutlu katsayı matrisi ve $\mathbf{U}_{\mathrm{t}}$ ise sıfır ortalamalı ve sabit varyanslı $(1 \mathrm{xg})$ boyutlu hata terimi vektörünü temsil etmektedir.

VAR modelin tahmininden elde edilen parametrelerin yorumlanması yerine, sistemin tahmininden elde edilen artıklar analiz edilerek geleceğe ilişkin yorumlar yapılabilir. VAR modelden elde edilen hatalara bir standart sapmalık şok verildiğinde diğer değişkenlerin bu şoka karşı verdikleri tepkiler, etki-tepki analizi ile belirlenir. Ayrıca belirlenen bir dönem sonunda ele alınan bir değişkenin diğer değişken ya da değişkenler tarafından yüzde kaçının açıklandığını gösteren varyans ayrıştırması, VAR modelin yorumlanmasında öncelik kazanmaktadır.

\section{Granger Nedensellik Testi}

Granger tarafından geliştirilen Granger nedenselliği, VAR modelde yer alan değişkenlerden bir ya da daha fazlasının diğerlerinin "Granger nedeni değildir" hipotezini test etmek için kullanılan yaygın kullanılan bir testtir (Davidson ve MacKinnon, 1999, s.588). Zaman serileri ile yapilan çalışmalarda nedensellik kavramı oldukça önemlidir. Granger tarafından 1969 yılında başlatılan iktisatta nedensellik testleri, uzun dönemli zaman serilerinde, durağan olma ve mevsimsel etki taşımaması koşuluyla değişkenler arasında nedenselliği belirlemektedir (Brooks, 2008, s.298).

Granger edensellik testi, iki değişkenli zaman serisi için aşağıdaki denklemler yardımıyla elde edilir: 


$$
\begin{aligned}
\mathrm{Y}_{\mathrm{t}} & =\phi_{0}+\sum_{\mathrm{j}=1}^{\mathrm{p}} \phi_{\mathrm{j}} \mathrm{Y}_{\mathrm{t}-\mathrm{j}}+\sum_{\mathrm{j}=1}^{\mathrm{p}} \varphi_{\mathrm{j}} \mathrm{X}_{\mathrm{t}-\mathrm{j}}+\mathrm{u}_{1 \mathrm{i}} \\
\text { - } \mathrm{X}_{\mathrm{t}} & =\varphi_{\mathrm{o}}+\sum_{\mathrm{j}=1}^{\mathrm{p}} \varphi_{\mathrm{j}} \mathrm{X}_{\mathrm{t}-\mathrm{j}}+\sum_{\mathrm{j}=1}^{\mathrm{p}} \phi_{\mathrm{j}} \mathrm{Y}_{\mathrm{t}-\mathrm{j}}+\mathrm{u}_{2 \mathrm{i}}
\end{aligned}
$$

Yukarıdaki eşitliklerde $\mathrm{p}$ gecikme sayısıdır. Bu eşitliklerde dikkate değer olan varsayım $\mathrm{u}_{1 \mathrm{i}}$ ve $\mathrm{u}_{2 \mathrm{i}}$ hata terimlerinin birbirinden bağımsız olmasıdır. (2) numaralı eşitlik için test edilen boş hipotez " $X$, Y'nin Granger nedenidir" şeklindedir. (3) numaralı eşitlik için boş hipotez ise "Y, X'in Granger nedenidir" şeklindedir.

\section{Ampirik Bulgular}

Bu çalışmada yapılan uygulamada İMKB işlem hacmi, Türkiye'de faaliyet gösteren bankalardaki toplam kredi hacmi ile toplam mevduat hacmi ve Türkiye'ye ait gayri safi yurt içi hasıla (1998 yılı sabit fiyatlarıyla) olmak üzere dört değişken arasındaki etkileşim incelenmiştir. Veriler TCMB'nin elektronik veri dağıtım sisteminden elde edilmiş olup 20022011 dönemi üçer aylık verilerden oluşmaktadır. Bilindiği gibi, serileri olası değişen varyans ve kısmen de otokorelasyona karşı koruyabilmek için serilerin logaritmik dönüşümleri alınmaktadır (Albayrak, 2008, s.116). Dolayısıyla bu çalışma kapsamında veriler analize doğal logaritmaları alınarak devam edilmiştir.

Zaman serileri analizinde değişkenler, üçer aylık bazda olduğu için mevsimsel etki araştırılmış ve bu etki Tramo-seat yöntemiyle arındırılmiştır. Söz konusu değişkenlere ait zaman serilerinde trend etkisi de Hodrick-Prescott filtresi ile arındırılmıştır. Son olarak serilerde birim kökün varlığı, diğer bir deyişle durağanlık, Düzeltilmiş Dickey-Fuller, Phillips-Perron ve Zivot-Andrews testleri ile araştırılmıştır.

2008'de Amerika Birleşik Devletleri'nde baş gösterip kısa sürede tüm dünyayı etkisi altına alan global finansal kriz, bu çalışma kapsamında ele alınan değişkenlerin dönemleri arasında yer aldığından, serilerde yapısal kırılma olup olmadığı Zivot-Andrews Yapısal kırılma testi ile araştırılmiştır.

Çalışma kapsamındaki değişkenlerin durağanlık testleri olan ADF ve PP test sonuçları Tablo 4'de gösterilmiştir. Buradaki sonuçlara göre 
LnIMMKB ve LnMevduatHacmi değişkenleri düzey değerlerde, LnGSYİH ve LnKrediHacmi değişkenleri birinci farklarda durağan oldukları hem ADF hem de PP testi sonuçları ile tespit edilmiştir.

Tablo 4. Değişkenlerin ADF ve PP Testi Sonuçları

\begin{tabular}{lllll}
\hline & \multicolumn{2}{l}{ ADF Test Sonuçları } & PP Test Sonuçları & Birinci \\
& Düzey & Birinci & Düzey & Farklar \\
& Değer & Farklar & $-2.019(-2.938)$ & $-4.917(-2.941)$ \\
\hline LnGSYİH & $-2.538(-2941)^{* *}$ & $-4.963(2.941)$ & - & - \\
\hline LniMKB & $-4.768(-2.938)$ & - & $-4.660(-2.938)$ & - \\
\hline LnKrediHacmi & $-2.782(-2.943)$ & $-6.020(-2.941)$ & $-2.706(-2.938)$ & $-6.049(-2.941)$ \\
\hline LnMevduatHacmi & $-3.628(-2.938)$ & - & $-3.644(-2.938)$ & - \\
\hline
\end{tabular}

*'Ln' ifadesi değiş̧kenlerin doğal logaritması alınmış halini temsil ettiğini belirtmektedir.

${ }^{* *}$ MacKinnon 0.05 önem düzeyine karşılık gelen kritik değeridir.

2008'de başlayan global krizin etkisinin, çalışma kapsaminda ele alınan değişkenlerde yapısal kırılmaya yol açıp açmadığı Zivot-Andrews testi ile araştırılmıştır. Çalışmanın ilk aşamasında serilerin trend etkisi Hodrick-Prescott filtresi ile arındırıldığı için yapısal kırılma sabitli ve trendli ve sabitli modeller için araştırılmıştır. Test sonuçları Tablo 5'dedir. Buradaki sonuçlara göre sabitli model için LnMevduatHacmi değişkeninde yapısal kırılma dikkate alınarak yapılan birim kök testinde sabitli model için 2006 yılının birinci çeyreği kırılma yılı olarak öne çıkıp, sabitli ve trendli modeller için 2004 yılının birinci çeyreği kırılma yılı olarak öne çıkarak serinin birim kök içerdiğini belirten boş hipotez reddedilememektedir. LnKrediHacmi değişkeni için sabitli ve trendli modelde kırılma yılı 2008 yılının üçüncü çeyreği olarak belirlenip serinin düzey değerde durağan olmadığı tespit edilmiştir.

Tablo 5: Zivot-Andrews Birim Kök Testi Sonuçları

\begin{tabular}{|c|c|c|}
\hline & Sabitli Model* & Sabitli ve Trendli Model** \\
\hline LnGSYİH & $-4.826(2008 \mathrm{Q} 2)$ & $-6.999(2008 Q 4)$ \\
\hline LnIMKKB & $-5.222(2003 \mathrm{Q} 4)$ & $-5.261(2006 \mathrm{Q} 3)$ \\
\hline LnKrediHacmi & $-5.012(2008 \mathrm{Q} 2)$ & $-4.535(2008 Q 3)$ \\
\hline LnMevduatHacmi & $-4.431(2006 \mathrm{Q} 1)$ & $-4.435(2004 Q 1)$ \\
\hline
\end{tabular}


Değişkenlerin birim kökleri incelenip hangi düzeyde durağan oldukları tespit edildikten sonra, VAR model için gerekli olan nedensellik ve dışsallık testi sonuçları Tablo 6'da verilmiştir. Granger tarafından geliştirilen dışsallık/nedensellik testi, değişkenlerin birbirlerinin Granger nedeni olup olmadığını tespit etmede kullanılmaktadır. Tablo 6'daki sonuçlara göre, 0.05 önem düzeyinde;

LnMevduatHacmi değişkeni $\Delta$ LnGSYİH'nin;

LnİMKB değişkeni $\Delta$ LnKrediHacmi'nin ve

LnMevduatHacmi, $\Delta$ LnKrediHacmi'nin

Granger nedeni olarak tespit edilmiştir.

Tablo 6. Granger Nedensellik/Dışsallık Testi Sonuçları

\begin{tabular}{|c|c|c|}
\hline Hipotezler & $\begin{array}{l}\text { Test } \\
\text { İstatistiği }\end{array}$ & $\begin{array}{l}\text { Test İstatistiği'nin } \\
\text { Olasılık Değeri }\end{array}$ \\
\hline LnİMKB, $\Delta$ LnGSYİH'nin* Granger nedeni değildir. & 1.990504 & 0.3696 \\
\hline $\begin{array}{l}\Delta \text { LnKrediHacmi, } \Delta \text { LnGSYİH'nin Granger } \\
\text { nedeni değildir. }\end{array}$ & 0.534190 & 0.7656 \\
\hline $\begin{array}{l}\text { LnMevduatHacmi, } \Delta \text { LnGSYİH'nin Granger } \\
\text { nedeni değildir. }\end{array}$ & 6.930818 & 0.0313 \\
\hline$\Delta$ LnGSYİH, LnİMKB'nin Granger nedeni değildir. & 2.722271 & 0.2564 \\
\hline$\Delta$ LnKrediHacmi, LnİMKB'nin Granger nedeni değildir. & 2.493802 & 0.2874 \\
\hline $\begin{array}{l}\text { LnMevduatHacmi, LnİMKB'nin Granger } \\
\text { nedeni değildir. }\end{array}$ & 2.892262 & 0.2355 \\
\hline $\begin{array}{l}\Delta \text { LnGSYİH, } \Delta \text { LnKrediHacmi'nin Granger } \\
\text { nedeni değildir. }\end{array}$ & 1.065125 & 0.5871 \\
\hline $\begin{array}{l}\text { LnİMKB, } \Delta \text { LnKrediHacmi'nin Granger } \\
\text { nedeni değildir. }\end{array}$ & 7.512033 & 0.0234 \\
\hline $\begin{array}{l}\text { LnMevduatHacmi, } \Delta \text { LnKrediHacmi'nin } \\
\text { Granger nedeni değildir. }\end{array}$ & 12.34105 & 0.0021 \\
\hline $\begin{array}{l}\Delta \text { LnGSYİH, LnMevduatHacmi'nin Granger } \\
\text { nedeni değildir. }\end{array}$ & 0.696429 & 0.7059 \\
\hline $\begin{array}{l}\text { LnIMKB, LnMevduatHacmi'nin Granger } \\
\text { nedeni değildir. }\end{array}$ & 5.445715 & 0.0657 \\
\hline $\begin{array}{l}\Delta \text { LnKrediHacmi, LnMevduatHacmi'nin } \\
\text { Granger nedeni değildir. }\end{array}$ & 2.273458 & 0.3209 \\
\hline
\end{tabular}

${ }^{*} \Delta$, Serilerin birinci farklarını göstermektedir.

VAR model için gerekli gecikme sayısının belirlenmesi için seçim kriterleri Tablo 7'da verilmiştir. Tablo 7'daki sonuçlara göre, olabilirlik oran1, son tahmin hatası ve Hannan-Quinn bilgi kriterine göre en uygun gecikme sayısı iki olarak VAR model oluşturulmuştur. 
Tablo 7. VAR Model İçin Uygun Gecikme Sayısı

\begin{tabular}{llllll}
\hline $\begin{array}{l}\text { Gecikme } \\
\text { Sayıs1 }\end{array}$ & $\begin{array}{l}\text { Olabilirlik } \\
\text { Oranı }\end{array}$ & $\begin{array}{l}\text { Ton } \\
\text { Tahmin }\end{array}$ & $\begin{array}{l}\text { Akaike } \\
\text { Bilgi Kriteri }\end{array}$ & $\begin{array}{l}\text { Schwarz } \\
\text { Bilgi Kriteri }\end{array}$ & $\begin{array}{l}\text { Hannan- } \\
\text { Quinn } \\
\text { Bilgi Kriteri }\end{array}$ \\
\hline 0 & NA & $1.67 \mathrm{e}-11$ & -13.46234 & $\mathbf{- 1 3 . 2 8 2 7 7 ^ { * }}$ & -13.40110 \\
\hline $\mathbf{1}$ & 36.94372 & $1.21 \mathrm{e}-11$ & -13.79508 & -12.89723 & -13.48889 \\
\hline $\mathbf{3}$ & $\mathbf{3 1 . 6 9 2 3 9 ^ { * }}$ & $\mathbf{9 . 1 1 e - 1 2 *}$ & -14.12160 & -12.50546 & $\mathbf{- 1 3 . 5 7 0 4 5 *}$ \\
\hline $\mathbf{3}$ & $\mathbf{1 5 . 3 8 9 4 4}$ & $1.26 \mathrm{e}-11$ & -13.91326 & -11.57882 & -13.11715 \\
\hline 5 & 12.59471 & $1.93 \mathrm{e}-11$ & -13.71295 & -10.66023 & -12.67188 \\
\hline
\end{tabular}

Şekil 1'de VAR modelin artıklarına verilen \pm 2 standart sapmalık şok karşısında diğer değişkenlerin nasıl tepki verdiğini gösteren etki-tepki fonksiyonları yer almaktadır. Granger nedensellik testi sonuçları ile beraber etki-tepki fonksiyonları incelendiğinde;

- $\Delta$ LnGSYİH değişkenine verilen \pm 2 standart sapmalık şok karşısında LnMevduatHacmi değişkeni ikinci dönem sonuna kadar durağan, ikinci dönemden üçüncü dönem sonuna kadar artış, üçüncü dönemden beşinci döneme kadar ise azalış yönünde tepki vermektedir.

- LnMevduatHacmi değişkenine verilen \pm 2 standart sapmalık şok karşısında $\triangle$ LnGSYİH değişkeni ise ikinci döneme kadar azalış, ikinci dönemden dördüncü döneme kadar artış yönünde tepki vermektedir.

- $\quad \Delta$ LnKrediHacmi'ne verilen \pm 2 standart sapmalık şok karşısında LnİMKB değişkeni ikinci döneme kadar artış, ikinci dönemden sonra azalış yönünde tepki vermektedir.

- LnİMKB'ye verilen \pm 2 standart sapmalık şok karşısında $\Delta$ LnKrediHacmi değişkeni ikinci döneme kadar artış, ikinci dönemden dördüncü döneme kadar azalış yönünde tepki vermektedir.

- $\quad \Delta$ LnKrediHacmi'ne verilen \pm 2 standart sapmalık şok karşısında LnMevduatHacmi ikinci döneme kadar durağan, ikinci dönemden üçüncü döneme kadar artış, üçüncü dönemden sonra ise azalış yönünde tepki vermektedir. 
- Son olarak LnMevduatHacmi değişkenine verilen \pm 2 standart sapmalık şok karşısında $\Delta$ LnKrediHacmi değişkeni azalış yönünde tepki vermektedir.

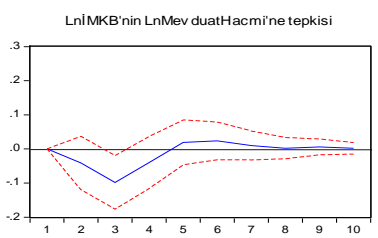

LnMev duatHacmi'nin LniMKB'y e tepkis

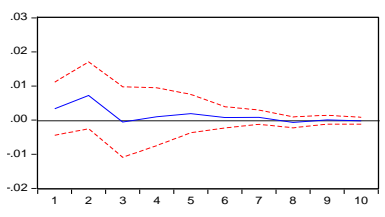

d(LnGSYiH)'nin LniMKB'y e tepkisi

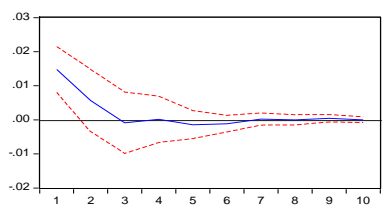

d(LnKrediHacmi)'nin LnMev duatHacmi'ne tepkisi

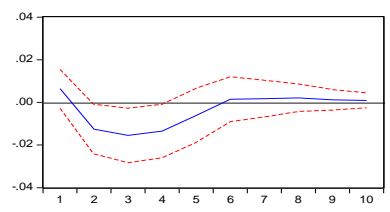

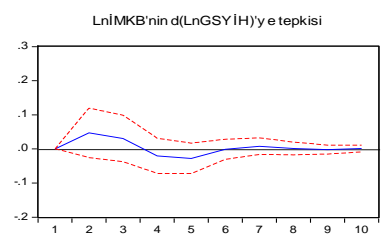

LnMev duatHacmi'nin d(LnGSYIH)'y e tepkisi

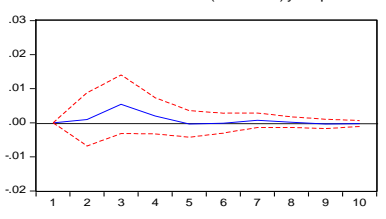

d(LnKrediHacmi)'nin d(LnGSYIH)'ye tepkisi

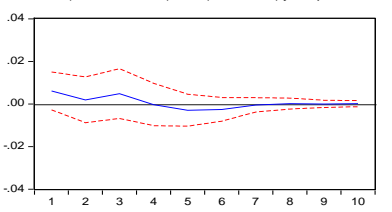

d(LnGSYiH)'nin LnMev duatHacmi'ne tepkisi

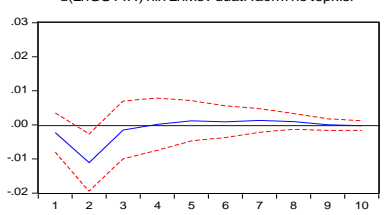

LniMKB'nin d(LnKrediHacmi)'ne tepkisi

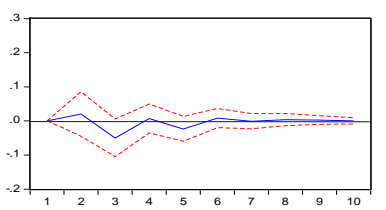

LnMev duatHacmi'nin d(LnKrediHacmi)'ne tepkisi

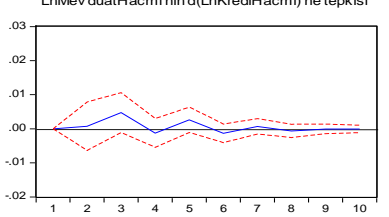

d(LnGSYiH)'nin d(LnKrediHacmi)'ne tepkisi

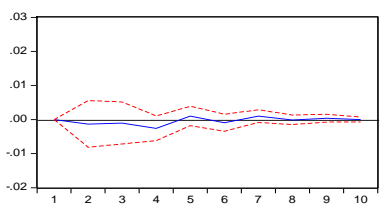

d(LnKrediHacmi)'nin Lni MKB'y e tepkisi

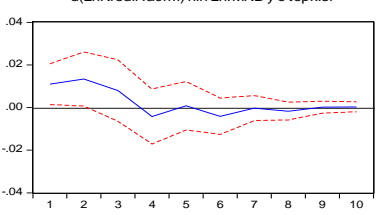

Şekil 1: VAR Modelden elde edilen Etki-Tepki Fonksiyonları

VAR modelden elde edilen bir diğer analiz de 'varyans ayrıştırma analizi'dir. Bir değişkenin değişkenliğinin, ele alınan dönem sonunda yüzde kaçının diğer değişken tarafından açıklandığı bu analiz yardımıyla elde edilir.

Tablo 8 VAR modele dahil edilen dört değişkenin yirmi dönem için varyans ayrıştırma sonuçlarını göstermektedir. VAR modelde dikkat edilmesi gereken önemli bir husus, değişkenlerin dişsaldan içsele doğru sıralanmasıdır. Varyans ayrıştırma analizinde, birinci dönem sonunda değişkenliğin tamamı kendisi tarafından açıklanan değişken en dışsal değişkendir. Tablo 8'deki sonuçlara incelendiğinde aşağıdaki bulgular dikkat çekmektedir; 
a) İMKB İşleme Hacmi: Birinci dönem sonunda değişkenliğinin tamamı (\%100'ü) kendisi tarafından açıklanan değişken LnİMKB değişkenidir. Bunun anlamı, modeldeki en dişsal değişken bu değişken olması anlamına gelmesidir. LnİMKB'nin değişkenliğinin, gelecek yirmi dönem sonunda, \%69.04'ü kendisi tarafından açıklanırken \%19.7'si LnMevduatHacmi, \%6.19'u $\triangle$ LnGSYİH ve geri kalan k1smı $\Delta$ LnKrediHacmi tarafından açıklanmaktadır.

b) Bankalar Mevduat Hacmi: LnMevduatHacmi'nin yirmi dönem sonundaki değişkenliğinin \%84.97'si gibi önemli kısmı kendisi tarafından açıklanırken \%7.57'si $\Delta$ LnIMMKB tarafından, \%3.78'i $\Delta$ LnGSYİH tarafından ve geri kalan kısmı $\triangle$ LnKrediHacmi tarafından açıklanmaktadır. Bu değişkenin, ilk dönemde, etkileşim içinde olduğu tek değişken 'IMKB İşlem Hacmi' olup, diğerleriyle herhangi bir etkileşimi görülmemiştir. Ancak, etkileşim de oldukça (sadece \%1.96) düşüktür.

c) Gayrisafi Yurtiçi Hasıla (Milli Gelir): $\triangle$ LnGSYİH'nin yirmi dönem sonundaki değişkenliğinin sadece \%43.5'i kendisi tarafından açıklanırken, \%35.72'si $\triangle$ LnIMKB tarafından, \%19'u LnMevduatHacmi tarafından ve geri kalan kısmı $\Delta$ LnKrediHacmi tarafından açıklanmaktadır. Bu değişkenin, ilk dönemde 'Banka Kredi Hacmi'ne 'duyarsız' olması dikkat çekerken, diğer değişkenlerden İMKB İşlem Hacmine karşı önemli bir 'bağımlılık' göstermesi dikkat çekmektedir. Ancak, ilk dönemdeki bu yüksek oranlı $(\% 41,45)$ bağımlılığın giderek azalması da bir başka önemli noktadır. Yani, Milli Gelir' in uzun dönemde İMKB İşlem Hacmi'ne duyarlılığı zayıflamaktadır. Ne var ki, diğer değişkenlere karşı bağımlılı̆̆ı uzun vadede en fazla olan değişken GSYİH'dır.

d) Bankalar Kredi Hacmi: Son olarak, $\Delta$ LnKrediHacmi değişkeninin yirmi dönem sonundaki değişkenliğinin \%48.45'i kendisi tarafından açıklanırken \%30.02'si LnMevduatHacmi tarafından, \%17.94'ü LnİMKB tarafindan ve geri kalan kısmı ise $\triangle$ LnGSYİH tarafından açıklanmaktadır. Bu değişken, ilk dönemde İMKB İşlem Hacmi'ne önemli bir bağımlılık içinde bulunmakta, hatta ikinci dönemde bu daha da artmaktadır. Ancak, sonraki dönemlerde yavaş yavaş bir azalış göstermekte, buna karşılık diğer değişkenlerin bağımlılı̆̆ı artmaktadır. 
Milli Gelir, Bankacılık Kredi ve Mevduat Hacmi ile Menkul Kıymetler Borsası İşlem Hacmi Etkileşimi

Tablo 8: VAR Modeldeki Değişkenlerin Varyans Ayrıştırma Sonuçları

\begin{tabular}{|c|c|c|c|c|}
\hline \multicolumn{5}{|c|}{ LnİMKB'nin Varyans Ayrıştırması } \\
\hline Dönem & LnIMKB & LnMevduatHacmi & $\Delta$ LnGSYIH & $\Delta$ LnKrediHacmi \\
\hline 1 & 100.0000 & 0.000000 & 0.000000 & 0.000000 \\
\hline 2 & 91.83304 & 3.224009 & 4.180415 & 0.762531 \\
\hline 3 & 73.62594 & 17.24010 & 4.740702 & 4.393260 \\
\hline 4 & 71.49649 & 18.97994 & 5.203159 & 4.320413 \\
\hline 5 & 69.83709 & 18.98637 & 6.177204 & 4.999340 \\
\hline 6 & 69.23038 & 19.59464 & 6.125069 & 5.049915 \\
\hline 7 & 69.12780 & 19.65805 & 6.183283 & 5.030864 \\
\hline 8 & 69.10898 & 19.65860 & 6.183090 & 5.049329 \\
\hline 9 & 69.06871 & 19.69167 & 6.185012 & 5.054610 \\
\hline 10 & 69.07113 & 19.69051 & 6.185036 & 5.053321 \\
\hline 11 & 69.05899 & 19.69440 & 6.192189 & 5.054425 \\
\hline 12 & 69.04783 & 19.70548 & 6.191332 & 5.055358 \\
\hline 13 & 69.04595 & 19.70648 & 6.192357 & 5.055216 \\
\hline 14 & 69.04537 & 19.70636 & 6.192613 & 5.055663 \\
\hline 15 & 69.04536 & 19.70634 & 6.192640 & 5.055661 \\
\hline 16 & 69.04542 & 19.70630 & 6.192627 & 5.055653 \\
\hline 17 & 69.04536 & 19.70634 & 6.192652 & 5.055649 \\
\hline 18 & 69.04527 & 19.70644 & 6.192646 & 5.055652 \\
\hline 19 & 69.04525 & 19.70644 & 6.192655 & 5.055651 \\
\hline 20 & 69.04524 & 19.70644 & 6.192660 & 5.055654 \\
\hline \multicolumn{5}{|c|}{ LnMevduatHacmi'nin Varyans Ayrıştırması } \\
\hline Dönem & LnIMKB & LnMevduatHacmi & $\Delta$ LnGSYIH & $\Delta$ LnKrediHacmi \\
\hline 1 & 1.962774 & 98.03723 & 0.000000 & 0.000000 \\
\hline 2 & 7.876524 & 91.94081 & 0.114987 & 0.067682 \\
\hline 3 & 7.087166 & 87.01924 & 3.343536 & 2.550059 \\
\hline 4 & 7.137942 & 86.39747 & 3.761524 & 2.703066 \\
\hline 5 & 7.444267 & 85.41346 & 3.733036 & 3.409241 \\
\hline 6 & 7.489281 & 85.19177 & 3.725170 & 3.593777 \\
\hline 7 & 7.542386 & 85.05577 & 3.768569 & 3.633274 \\
\hline 8 & 7.573726 & 84.99518 & 3.763265 & 3.667828 \\
\hline 9 & 7.572164 & 84.98410 & 3.776807 & 3.666931 \\
\hline 10 & 7.575038 & 84.97548 & 3.782885 & 3.666597 \\
\hline 11 & 7.574762 & 84.97533 & 3.782908 & 3.666996 \\
\hline 12 & 7.575587 & 84.97286 & 3.783399 & 3.668157 \\
\hline 13 & 7.575577 & 84.97270 & 3.783435 & 3.668291 \\
\hline 14 & 7.575832 & 84.97201 & 3.783411 & 3.668744 \\
\hline 15 & 7.575839 & 84.97193 & 3.783469 & 3.668766 \\
\hline 16 & 7.575857 & 84.97183 & 3.783533 & 3.668783 \\
\hline 17 & 7.575856 & 84.97183 & 3.783530 & 3.668788 \\
\hline 18 & 7.575860 & 84.97181 & 3.783542 & 3.668789 \\
\hline 19 & 7.575861 & 84.97181 & 3.783543 & 3.668789 \\
\hline 20 & 7.575862 & 84.97180 & 3.783543 & 3.668791 \\
\hline \multicolumn{5}{|c|}{$\Delta$ LnGSYIH'in Varyans Ayrıştırması } \\
\hline Dönem & LnIMKB & LnMevduatHacmi & $\Delta$ LnGSYIH & $\Delta$ LnKrediHacmi \\
\hline 1 & 41.45011 & 0.963073 & 57.58681 & 0.000000 \\
\hline 2 & 36.56407 & 18.73964 & 44.44418 & 0.252115 \\
\hline 3 & 36.23315 & 18.83133 & 44.53014 & 0.405380 \\
\hline
\end{tabular}




\begin{tabular}{|c|c|c|c|c|}
\hline 4 & 35.82119 & 18.61996 & 44.20523 & 1.353618 \\
\hline 5 & 35.87805 & 18.69359 & 43.93199 & 1.496375 \\
\hline 6 & 35.90620 & 18.73009 & 43.74329 & 1.620421 \\
\hline 7 & 35.77555 & 18.88726 & 43.58553 & 1.751662 \\
\hline 8 & 35.72580 & 18.99783 & 43.52539 & 1.750982 \\
\hline 9 & 35.72941 & 18.98648 & 43.51526 & 1.768851 \\
\hline 10 & 35.72539 & 18.99152 & 43.51443 & 1.768664 \\
\hline 11 & 35.72440 & 18.99858 & 43.50843 & 1.768590 \\
\hline 12 & 35.72395 & 18.99942 & 43.50806 & 1.768565 \\
\hline 13 & 35.72331 & 19.00000 & 43.50726 & 1.769433 \\
\hline 14 & 35.72336 & 19.00013 & 43.50707 & 1.769444 \\
\hline 15 & 35.72339 & 19.00006 & 43.50697 & 1.769583 \\
\hline 16 & 35.72329 & 19.00022 & 43.50688 & 1.769611 \\
\hline 17 & 35.72325 & 19.00032 & 43.50682 & 1.769608 \\
\hline 18 & 35.72325 & 19.00032 & 43.50682 & 1.769616 \\
\hline 19 & 35.72325 & 19.00032 & 43.50682 & 1.769618 \\
\hline 20 & 35.72325 & 19.00032 & 43.50682 & 1.769618 \\
\hline \multicolumn{5}{|c|}{$\Delta$ LnKrediHacmi'nin Varyans Ayrıştırması } \\
\hline Dönem & $\Delta$ LnIMKB & LnMevduatHacmi & $\Delta$ LnGSYIH & $\Delta$ LnKrediHacmi \\
\hline 1 & 13.17493 & 4.464018 & 4.037214 & 78.32384 \\
\hline 2 & 21.18951 & 14.06975 & 2.862234 & 61.87850 \\
\hline 3 & 19.86962 & 24.10681 & 3.509049 & 52.51453 \\
\hline 4 & 17.79533 & 29.09692 & 3.001760 & 50.10599 \\
\hline 5 & 17.43342 & 30.17027 & 3.339605 & 49.05670 \\
\hline 6 & 17.91115 & 29.77147 & 3.585156 & 48.73223 \\
\hline 7 & 17.88714 & 29.86436 & 3.589364 & 48.65913 \\
\hline 8 & 17.95664 & 29.96538 & 3.578035 & 48.49995 \\
\hline 9 & 17.94681 & 30.00665 & 3.575888 & 48.47065 \\
\hline 10 & 17.93796 & 30.02342 & 3.573747 & 48.46487 \\
\hline 11 & 17.94051 & 30.02131 & 3.576474 & 48.46170 \\
\hline 12 & 17.94174 & 30.02210 & 3.578320 & 48.45784 \\
\hline 13 & 17.94053 & 30.02536 & 3.578084 & 48.45602 \\
\hline 14 & 17.94049 & 30.02652 & 3.578172 & 48.45482 \\
\hline 15 & 17.94061 & 30.02643 & 3.578217 & 48.45474 \\
\hline 16 & 17.94062 & 30.02642 & 3.578219 & 48.45473 \\
\hline 17 & 17.94070 & 30.02642 & 3.578223 & 48.45466 \\
\hline 18 & 17.94069 & 30.02647 & 3.578228 & 48.45461 \\
\hline 19 & 17.94068 & 30.02650 & 3.578226 & 48.45459 \\
\hline 20 & 17.94067 & 30.02651 & 3.578229 & 48.45459 \\
\hline
\end{tabular}

\section{Tartışma ve Sonuç}

On yılı bulan bir dönemde analiz kapsamındaki değişkenlerde ortaya çıkan değişimin en yüksek oranda kendisi tarafından açıklandığı değişken 'Bankalar Mevduat Hacmi', en düşük oranda açıklandığı değişken ise GSYİH'dir. Buna göre, GSYİH değişkeni, diğer değişkenlerle önemli bir ilişki veya bağımlılık içinde görünmektedir. Yine uzun dönemde, 
diğer üç değişkendeki değişimi açıklamada en düşük orana sahip değişken 'Bankalar Kredi Hacmi' görülmektedir.

Böylece, 'Bankalar Mevduat Hacmi', diğer değişkenlerdeki değişimi açıklama kapasitesi, diğerlerine göre en güçlü değişken olarak belirlenirken, 'Bankalar Kredi Hacmi'nin diğer değişkenlerdeki değişimi açılama kapasitesi, diğerlerine göre en zayıf değişken olduğu tespit edilmiştir.

Analiz kapsamındaki değişkenlerde uzun dönemde ortaya çıkan değişimlerin, diğer değişkenlerle olan ilişkisi aşağıdaki gibi özetlenebilir;

a- İlk dönem sonunda ortaya çıkan değişkenliğinin tamamı kendisi tarafından açıklanan tek değişken, sadece İMKB İşlem Hacmi'dir.

b- 'Bankalar Mevduat Hacmi'nin yirmi dönem sonundaki değişkenliğinin \%84.97'si gibi önemli kısmı kendisi tarafından açıklanmakta ve en yüksek açıklama gücü olarak dikkat çekmektedir. Böylece, diğer değişkenlere, uzun dönemde en az bağımlılık gösteren değişken 'Bankalar Mevduat Hacmi' olmuştur. Buna karşıllı, beklendiği gibi GSYİH'nin yirmi dönem sonundaki değişkenliğinin sadece çok az bir (\%43.5) kısmı kendisi tarafından açılanmaktadır. Uzun dönemde ise, en fazla bağımlılık gösterdiği değişken ise 'İMKB İşlem Hacmi' dir.

c- 'Bankalar Kredi Hacmi' değişkeninin uzun dönemdeki değişkenliğinin \%48.45'lik kısmı kendisi tarafından açıklanırken, 'Bankalar Mevduat Hacmi'nden kaynaklanan değişim oranı \%30'u aşmakta, \%18'lik kısmı ise, 'İMKB İşlem Hacmi' tarafından açılanması dikkat çekmektedir.

$\mathrm{Bu}$ arada, çalışma kapsamındaki değişkenlerle oluşturulan VAR modelde, diğer değişkenler tarafından en fazla etkileşimin hissedildiği değişkenin 'Bankalardaki Kredi Hacmi' olduğu tespit edilmiştir. Granger nedensellik testi sonuçlarına göre, 'Bankalardaki Kredi Hacmi'nin İMKB İşlem Hacmi'nin ve Bankalardaki Mevduat Hacmi'nin Granger nedeni olduğu bulunmuştur. VAR modelden elde edilen etki-tepki fonksiyonları, bu sonuçların teoriye ve önceki çalışmalara uygunluğunu göstermektedir.

$\mathrm{Bu}$ çalışmanın ortaya koyduğu diğer önemli nokta; 2002 yılının son aylarında başlayan ve günümüzde de görevi devam eden mevcut hükümetin ekonomi ve finansal sistem içindeki politikalarının, bir bakıma incelenmesi ve değerlendirilmesi yapılmıştır. 2002-2011 dönemlerini kapsayan bu analiz dönemi içinde patlak veren ve halen etkileri kısmen 
de olsa süren 2008 küresel krizi bulunmaktadır. Bu krizin, çalışma kapsamındaki değişkenlerde neden olduğu, 'yapısal kırılma' test edilmiştir. Test sonucunda, 'Bankalar Mevduat Hacmi', 2004 yılının ilk çeyreği ile 2006 yılının ilk çeyreğinde 'kırılma' yaşadığı tespit edilmiştir. 'Bankalar Kredi Hacmi'nde ise, 2008 yılının üçüncü çeyreği 'kırılma dönemi' olarak belirlenmiştir. Böylece, 2007 yılı sonbaharında başlayan küresel kriz 'Bankalar Mevduat Hacmi'ne kriz öncesi yansırken, 'Bankalar Kredi Hacmi'ne krizin başlamasından itibaren yansımıştır.

Çalışma sonunda ulaşılan sonuçlar, başta ekonomik politika belirleyicileri olmak üzere, yatırımcılar, işletme yöneticileri, araştırmacılar ve ilgili birçok kesim için önemli ve yararlıdır. Kıt olan kaynakların en verimli ve etkinlikte kullanılması, her tür finansal göstergelerin diğerleri ile olan ilişkisi, bağımlık veya dışsallıklarının bilinmesini zaruri kılmaktadır. O nedenle, karar vericilerin başta politik tercih ve stratejiler ile işletme stratejilerini oluşturma aşamasında, istatistiksel/bilimsel araştırma sonuçlarını göz önünde bulundurmaları yararlı olacaktır. Ancak, bu çalışma kapsamındaki değişkenler oldukça sınırlı olduğundan, bunların yeterli olmadığ tejiler için bir çok değişkenin daha analize dahil edilmesi halinde çok özel kararların belirlenmesinde sağlanacak katkı ve sonuçta elde edilecek yarar daha da artabilecektir. 


\title{
EXTENDED ABSTRACT
}

\section{Interaction of National Income, Banking Credit, Deposit Volume and Stock Exchange Transaction Volume}

\author{
* \\ Mustafa Canbaz \\ Afyonkarahisar Health Science University
}

Gross national income and financial indicators are important data on the development of countries. Although countries are classified on the basis of these indicators, other social indicators are also determinative. This study was conducted to investigate the interaction between bank deposits and loans and the trading volume variables in the gross national income and equities market. In addition, it was investigated whether the 2008 crisis experienced during the analysis period had structural refraction on the variables. The data for the period between 2002 and 2011 of these four variables were taken into the scope of the study. The basic method used in analysis is the vector autoregressive (VAR) model.

In a period of ten years, the variable that revealed the highest rate of change in the variables covered by the analysis is the variable with the lowest deposit volume. Accordingly, the GDP variable appears to have a significant relationship or dependence with other variables. Again, in the long term, Banks' Credit Volume is the variable with the lowest rate in explaining the changes in the other three variables. Thus, while the Capacity of Banks Deposits to explain changes in other variables is determined as the strongest variable compared to others, the Capacity of Banks Loan Volume to explain changes in other variables is found to be the weakest variable.

The relationship between long term changes in variables within the scope of analysis and other variables can be summarized as follows;

* At the end of the first period, the only variable explained by itself is the ISE Trading Volume.

$84.97 \%$ of the volatility of the Banks' Deposit Volume at the end of the twenty-term period is explained by itself and attracts attention as the highest disclosure power. Thus, değişken Banks Deposits Volume 'was 
the variable that showed the least dependence on other variables in the long run. However, as expected, only a small part (43.5\%) of the variability of GDP at the end of the twenty periods is explained by itself. In the long run, the most dependent variable is the ISE Trading Volume.

* While $48.45 \%$ of the long-term variability of the Banks Loan Volume variable is explained by itself, the change rate arising from the Banks Deposit Volume exceeds $30 \%$, and $18 \%$ is explained by the ISE Transaction Volume.

Meanwhile, in the VAR model formed with the variables within the scope of the study, it was found that the variable with the most interaction among other variables was Credit Volume in Banks. According to the results of Granger causality test, it is found that the ISE Transaction Volume of Banks' Loan Volume and the Deposit Volume of Banks are the Granger Causes. The effect-response functions obtained from the VAR model demonstrate the relevance of these results to theory and previous studies.

Another important point revealed by this study; The policies of the current government in the economic and financial system, which started in the last months of 2002 and continues to serve today, have been examined and evaluated in a way. During this analysis period, which covers the period of 2002-2011, there is a 2008 global crisis that erupted and still has partial effects. The structural break caused by this crisis in the variables covered in the study was tested. As a result of the test, it was determined that Banks Deposit Volume experienced a break in the first quarter of 2004 and in the first quarter of 2006. In the Loan Volume of Banks, the third quarter of 2008 was determined as the breaking period. Thus, the global crisis that started in the autumn of 2007 was reflected in the Banks Deposit Volume before the crisis, while the Banks' Credit Volume was reflected since the onset of the crisis.

The conclusions reached at the end of the study are important and useful for economic policy makers, investors, business managers, researchers and many other stakeholders. The use of scarce resources in the most efficient and effective manner and the relationship of all financial indicators with others make it necessary to know their dependency or externality. For this reason, it will be useful for decision makers to consider the results of statistical / scientific research, especially in the 
stage of forming political preferences and strategies and business strategies. However, it is obvious that these variables are not sufficient as the variables in this study are quite limited. In fact, if many variables are included in the analysis for political or economic preferences or strategies, the contribution and ultimately the benefit to be made in determining very specific decisions may increase.

\section{Kaynakça / References}

Acar, F., (2013). Türkiye ekonomisine genel bakış:(2001 - 2013). ÇSGB Çalışma Dünyası Dergisi, 1(2), 15-32

Albayrak, A. S., (2008). Değişen varyans durumunda en küçük kareler tekniğinin alternatifi ağılıklı regresyon analizi ve bir uygulama. Afyon Kocatepe Üniversitesi I.I.I.B.F. Dergisi, 10(2), 111-134

Alkin, E., (2009). Herkes için ekonomi. İstanbul:İstanbul Ticaret Odası Yayını.

Babacan, A., (2010). Yükselen değer Türkiye: Genel makroekonomik görünüm. içinde (s. 189-198), İstanbul:Müsiad Yayını.

Barışık, S. ve Çevik, E., (2010). Türkiye'de 2000 sonrasında ekonomik konjonktürün tahmininde İMKB ve izdırap endeksi etkileşim analizi, 9. Ulusal İsletmecilik Kongresi, 6-8 Mayıs Zonguldak, 162-164.

BDDK, (2010). Krizden istikrara Türkiye tecrübesi:Çalışma tebliği (Gözden Geçirilmiş 3. bsk), Ankara:BDDK Yayınları.

Brooks, C. (2008). Introductry econometrics for finance. (2. Bs), Cambridge, UK:Cambridge University Press.

Davidson, R. ve MacKinnon, J. G., (1999). Econometric theory and methods. New York, USA:Oxford University Press.

Dickey, D. A. ve Fuller, W. A., (1979). Distribution of the estimators for autoregressive time series with a unit root, Journal of the American Statistical Association, 74(366), 427-431

Direkçi, T., (2006). Kamu açılarının makro ekonomik etkileri: Türkiye çalışması. Doktora Tezi, Çukurova Üniversitesi Sosyal Bilimler Enstitüsü, Adana.

Erdinç, Y. (2004). Yatırımcı ve teknik analiz sorgulanıyor. Ankara:Siyasal Kitabevi.

Ersan, İ. ve Günay, S., (2009). Kredi riski göstergesi olarak kredi temerrüt swapları (CDSs) ve kapatma davasının Türkiye riski üzerine etkisine dair bir uygulama. Bankacilar Dergisi, 71, 3-22. 
Ertuğrul, M., (2008). Değer-fiyat ayrimi ve işletme değeri: Kuramsal bir bakış. Eskişehir Osmangazi Üniversitesi İ̈BF Dergisi, 3(2), 143-154

Ferguson, N. (2012). Paranın yükselişi. (B. Pala Çev.), (2. Bs), İstanbul:YKY.

Göçer, İ., ve Mercan, M., ve Bölükbaş, M. (2015). Bankacilık sektörü kredilerinin istihdam ve ekonomik büyüme üzerindeki etkileri: Türkiye ekonomisi için çoklu yapısal kırılmalı eş bütünleşme analizi. Hacettepe Üniversitesi İktisadi ve İdari Bilimler Fakültesi Dergisi, 33(2), 65-84

Granger, C. W. J., (1969). Investigating causal relations by econometric models and cross-spectral methods. Econometrica, 37(3), 424-438

Heffernan, S., (2005). Modern banking. England:John Wiley \& Sons, Ltd.

Işık, N. (2005). Enflasyonla Mücadelede politika aracı seçimi: Bir vektör otoregresyon (VAR) analizi, Selçuk Üniversitesi Sosyal Bilimler Enstitüsü Dergisi, 14, 341-354.

Karacaoğlan, Ç. (2011). Yabancı bankaların Türk bankacıllk sektörüne girişi. Yayınlanmamış MBA Tezi, Kadir Has Üniversitesi Sosyal Bilimler Enstitüsü, İstanbul.

Karahan, Ö., Yılgör, M. ve Özekin, A. A., (2018). Türkiye'de banka kredilerindeki genişleme ile ekonomik büyüme arasındaki ilişki, Finans Politik \& Ekonomik Yorumlar, 55(636), 25-36

Kılıç, M., (2018). Kredi hacminin ekonomik büyüme üzerine etkisi: Türkiye üzerine bir analiz, Social Sciences Studies Journal (SSSJournal), 4(15), 1036-1043

Korkmaz, T. ve Çevik, E. İ., (2008). Petrol fiyat şoklarının Türkiye'de makro ekonomik değişkenler üzerindeki Etkisi, 12. Ulusal Finans Semроzуити, 22-25 Ekim, Kayseri, 157-178.

Lebe, F. ve Bayat, T., (2011). Taylor kuralı: Türkiye için bir vektör otoregresif model analizi. Ege Akademik Bakı̧̧ Dergisi, 11( Özel Sayı), 95-112.

Mercan, M., (2013). Kredi hacmindeki değişimlerin ekonomik büyümeye etkisi: Türkiye ekonomisi için sınır testi yaklaşımı, Bankacılar Dergisi, 84, 54-71

Parasız, M. İ., (1997). Para banka ve finansal piyasalar:Teori ve politikalar. Bursa:Ezgi Kitabevi.

Peker, O. ve Canbazoğlu, B., (2011). Türkiye'de banka kredi kanalının işleyişi: Ampirik bir analiz, Celal Bayar Üniversitesi İ̈BF Yönetim ve Ekonomi Dergisi, 18(2), 127-143

Phillips, P. C. ve Perron, P., (1988). Testing for a unit root in time series regression. Biometrika, 75, 335-46 
Şakar, B., (2011). Banka kredileri ve yönetimi. (3. Bs), İstanbul:Beta Basım Yayın Dağıtım A.Ş.

TBB. (2013). Bankalarımız 2012. Türkiye Bankalar Birliği Yayın No: 294.

Tiryaki, G. (2012). Finansal istikrar ve bankacllk düzenlemeleri:1990-2010 Türkiye tecrübesi işı̆̆ında. İstanbul:TBB.

Turgut, A. ve Ertay, H. A., (2016). Bankacılık sektörünün ekonomik büyüme üzerindeki etkisi: Türkiye üzerine nedensellik analizi, Aksaray Üniversitesi İktisadi ve İdari Bilimler Fakültesi Dergisi, 8(4), 114-128.

Tuna, K. ve Bektaş, H., (2013). Kredi hacminin ekonomik büyüme üzerindeki rolünün incelenmesi: Türkiye örneği. Journal of Financial Researches \& Studies / Finansal Araştırmalar ve Çalışmalar Dergisi, 5(9), 139-150)

Uludağ, İ. ve Arıcan, E., (2001). Finansal hizmetler ekonomisi:Piyasalar, kurumlar, araçlar. İstanbul:Beta Basım Yayın Dağıtım A.Ş.,

Vurur, N. S. ve Özen, E., (2013). Türkiye'de mevduat banka kredisi ve ekonomik büyüme ilişkisinin incelenmesi, Uşak Üniversitesi Sosyal Bilimler Dergisi, 6(3), 117-131

Yetiz, F., (2016). Bankacilığın doğuşu ve Türk bankacılık sistemi, Niğde Üniversitesi İktisadi ve İdari Bilimler Fakültesi Dergisi, 9 (2), 107-117

\section{Kaynakça Bilgisi / Citation Information}

Canbaz, M. (2019). Milli gelir, bankacilık kredi ve mevduat hacmi ile menkul kıymetler borsası işlem hacmi etkileşimi. OPUSUluslararası Toplum Araştırmaları Dergisi, 13(19), 2592-2626. DOI: 10.26466/opus.588751 